\title{
TRANSFER OF IRON FROM SERUM IRON-BINDING PROTEIN TO HUMAN RETICULOCYTES *
}

\author{
By JAMES H. JANDL, JOHN K. INMAN, RICHARD L. SIMMONS, AND \\ DAVID W. ALLEN \\ (From the Thorndike Memorial Laboratory and Second and Fourth (Harvard) Medical Serv- \\ ices, Boston City Hospital, and the Department of Medicine, Harvard Medical \\ School, Boston, Mass.)
}

(Submitted for publication August 7, 1958; accepted September 11, 1958)

The metabolism of iron involves a series of compounds which restrict iron to undissociated forms. Upon absorption by gut mucosal cells, iron is enveloped within ferritin molecules $(1,2)$. In the presence of reducing agents, ferritin iron then is released to the surfaces of ferritin molecules (3) to become bound by a specialized transport protein of the plasma. ${ }^{1}$ This iron-binding protein (IBP) is a $\beta_{1}$ globulin by electrophoretic analysis but resembles albumin in chemical properties $(5,8)$. Each molecule of IBP from human plasma or from the plasma of several other mammalian species studied, in common with the IBP of egg white, "conalbumin," binds two iron atoms to form a colored complex (5, 9-12). Iron bound by these proteins is in the ferric state ( 5 , 8) and is tightly chelated in complexes which apparently contain three phenolic groups and one bicarbonate ion $(7,11,12)$. At a physiologic $\mathrm{pH}$ and bicarbonate concentration the iron-IBP complex is extremely stable. In some manner, however, iron is transferred from IBP to immature red cells for incorporation into heme. Although it is well established that immature red cells, either as intact cells or as hemolysates, can utilize ionic iron for heme synthesis (13-20), little is known of the mechanism releasing iron from plasma IBP for cellular utilization. It is often assumed that this mechanism for transfer-

* This investigation was supported in part by a grant from the Helen Hay Whitney Foundation, and by a research grant, P. H. S. No. RG3507 (C5), from the National Institutes of Health, Public Health Service.

1 Although several metals, including $\mathrm{Cu}^{++}, \mathrm{Zn}^{++}(4,5)$, $\mathrm{Co}^{+++}$and $\mathrm{Mn}^{+++}$(6) may combine with this protein, its sole known physiologic function is to transport iron through plasma. Thus the terms transferrin (4), siderophyllin (7), and iron-binding protein, of which the last will be employed in this report, are perhaps preferable to less specific terms such as metal-binding protein or metalcombining globulin. ring iron from IBP to immature red cells includes transition through marrow iron storage sites. Recently, indeed, Bessis and Breton-Gorius (21, 22) have interpreted their electron-microscopic studies of immature red cells to indicate that erythroblasts may obtain iron for hemoglobin synthesis by removing iron particles from contiguous macrophages. The physical disadvantages of such a system as compared to a soluble transfer system are great, however, and the observation by Walsh and co-workers (15) that intact immature red cells (human reticulocytes) are capable of taking up iron bound to plasma in vitro suggests that normally iron is transferred directly from IBP to immature red cells.

The interaction between IBP and immature red cells represents a physiologic transfer system peculiarly susceptible to study in vitro. Observations characterizing this interaction, partially described in a preliminary report (23), are presented below.

\section{MATERIALS}

Iron-binding protein of a high degree of purity was prepared as described elsewhere by Inman (24), using as a starting material Fraction IV-7, obtained by standard ethanol fractionation procedures and saturated with iron. ${ }^{2}$ After recrystallization six times this material was analyzed by electrophoresis and found to contain 97.6 per cent iron-binding protein. Its molecular weight was calculated from data obtained by ultracentrifugation and by diffusion to be 87,000 (6).

Iron-saturated conalbumin, prepared from hen's eggs, was generously supplied by Dr. Robert C. Warner. ${ }^{8}$ The

2 In this method the $\mathrm{pH}$ is not reduced below 5.2. Below a $\mathrm{pH}$ of 5 , this protein is at least partially denatured. Partial denaturation of IBP during its preparation presumably accounts for differences reported (25) in the turnover of iron bound to unaltered plasma IBP as compared to iron bound to certain commercial fractions of IBP.

${ }^{3}$ Department of Biochemistry, New York University College of Medicine, New York, N. Y. 
iron in this material was removed by dialysis against a 0.4 per cent solution of the disodium salt of ethylenediaminetetraacetic acid (EDTA) * in physiologic saline adjusted to $\mathrm{pH} 5.6$, and EDTA was subsequently removed by repeated dialysis against iron-free saline buffered at $\mathrm{pH}$ 7.4. Throughout these experiments $\mathrm{Fe}^{50 \mathrm{~s}}$ was derived from dilute acid solutions of radioactive ferric chloride to which four parts of stable carrier iron were usually added. Studies of cobalt utilization by red cells were carried out with $\mathrm{Co}^{\circ{ }^{60} \mathrm{Cl}_{2} \text {. }}$

Whole heparinized blood samples rich in reticulocytes were generally obtained from patients either with pernicious anemia during therapeutic response or with hemolytic anemias. In certain instances the proportion of reticulocytes was increased by centrifuging and withdrawing the top portion of packed red cells. Finally, saline suspensions of red cells were usually prepared by washing the specimens of heparinized peripheral blood three times by centrifugation in approximately 20 volumes of ironfree physiologic saline. For the sake of brevity such reticulocyte-rich red cell suspensions are referred to below in many places simply as "reticulocytes."

\section{METHODS}

Hematocrit and hemoglobin values of the washed red cell preparations were determined by standard methods (26) ; reticulocytes were enumerated by the dry method (26) after resuspension of a drop of washed cells in two drops of plasma.

Complexing of iron and IBP was produced by slowly adding $\mathrm{Fe}^{50} \mathrm{Cl}_{8}$ to solutions of IBP in iron-free physiologic saline containing $10^{-2} \mathrm{M} \mathrm{NaHCO}_{3}$. This mixture was allowed to react for one hour at room temperature before addition to red cells, although color due to the formation of the Fe-IBP complex regularly reached a maximum within a few minutes of admixture.

Cobalt and manganese also form stable colored complexes with IBP and, as with iron, the trivalent state is required for this reaction (6). Unlike iron, which autooxidizes readily to the ferric state under physiologic conditions, cobalt requires the presence of an oxidant in order to remain in the cobaltic form. Thus one-tenth volume of $0.1 \mathrm{M} \mathrm{H}_{2} \mathrm{O}_{2}$ was added to the reaction mixture containing $\mathrm{Co}^{\infty} \mathrm{Cl}_{2}, \mathrm{NaHCO}_{3}$ and IBP.

In the majority of experiments a $30 \mu \mathrm{M}$ concentration of IBP was employed and equal volumes of 20 or $30 \mu \mathrm{M}$ concentrations of metal were added, resulting in one-third and one-half saturation, respectively, of the iron-binding capacity of IBP. Actual determinations of the iron-binding capacity of purified IBP, plasma or serum were made by the method of Rath and Finch (27), and iron concentrations were measured by the method of Kitzes, Elvehjem and Schuette (28).

Following addition of washed red cells to the $\mathrm{Fe}^{\mathrm{s}}$ - or $\mathrm{Co}^{\circ 0}$-containing test mixtures of the type described above,

4 "Sequestrene," three times recrystallized, Alrose Chemical Company, Providence, R. I.

s Abbott Laboratories, North Chicago, Ill. the mixed suspensions were incubated at $37^{\circ} \mathrm{C}$. with agitation. At the end of the incubation period the red cells were washed with physiologic saline five times. The packed washed red cells were then diluted with physiologic saline to a given volume in volumetric flasks, from which $3 \mathrm{ml}$. samples were withdrawn for determination of whole red cell radioactivity in a well-type scintillation counter. The red cell radioactivity was compared to that of the standards, and the red cell uptake of metal was generally expressed as micrograms of metal per milliliters of cells.

The fraction of radioactivity not present in the red cell membranes was estimated in most experiments by centrifuging $5 \mathrm{ml}$. of the final cell suspension and hemolyzing the sedimented cells with $3 \mathrm{ml}$. of distilled water; $0.7 \mathrm{ml}$. of 5 per cent $\mathrm{NaCl}$ was then added, and the suspension was made up to volume in a $5 \mathrm{ml}$. volumetric flask with 0.85 per cent saline. The hemolyzed suspension was then centrifuged clear of cell membranes at approximately $1,000 \mathrm{G}$ for 15 minutes and the supernatant solution was assayed for radioactivity. The localization of $\mathrm{Fe}^{\mathrm{s \theta}}$ in red cell fractions was more precisely defined in certain instances by differential centrifugation of hemolysates with an ultracentrifuge. ${ }^{8}$ The incorporation of $\mathrm{Fe}^{\mathrm{s}}$ into heme was determined in certain experiments by measuring the radioactivity of heme extracted from the red cells by the method of Fischer (29).

In order to estimate simply and simultaneously the distribution of $\mathrm{Fe}^{\mathrm{s0}}$ between hemoglobin, IBP and the red cell membranes, filter paper electrophoresis and autoradiography were employed. In this procedure, the washed reticulocytes were suspended in equal volumes of saline and hemolyzed by repeated freezing and thawing. At $\mathrm{pH}$ 6.35 , midway between the isoelectric points of IBP (5.9) and hemoglobin (6.8), these two proteins migrated oppositely, whereas the particulate matter of the cells remained precipitated at the origin. The proportion of radioactivity traveling with the hemoglobin spot was determined by planimetric analysis and quantitated by comparison with autoradiographs of various dilutions of the $\mathrm{Fe}^{\mathrm{so}}$ standard. In intact cell systems, good conformity appeared between measurement of hemoglobin incorporation of $\mathrm{Fe}^{\mathrm{\infty}}$ by this method, and heme incorporation of $\mathrm{Fe}^{\mathrm{\infty}}$ by the method of Fischer. By the autoradiograph method, over 80 per cent of the radioactivity of supernatant solutions derived from water hemolysates of $\mathrm{Fe}^{\mathrm{s}}$-labeled reticulocytes, prepared as described above, resided in the hemoglobin spot.

\section{RESULTS}

\section{The uptake of $\mathrm{Fe}^{59} \mathrm{Cl}_{3}$ from saline by mature and immature red cells}

$\mathrm{Fe}^{59}$ from a saline solution of $\mathrm{Fe}^{59} \mathrm{Cl}_{3}$ was bound to, or adsorbed onto, both mature and immature red cells (Figure 1). The uptake of radioactive $\mathrm{Fe}^{+++}$by both mature and immature

\footnotetext{
6 Spinco Model L Preparative Ultracentrifuge.
} 


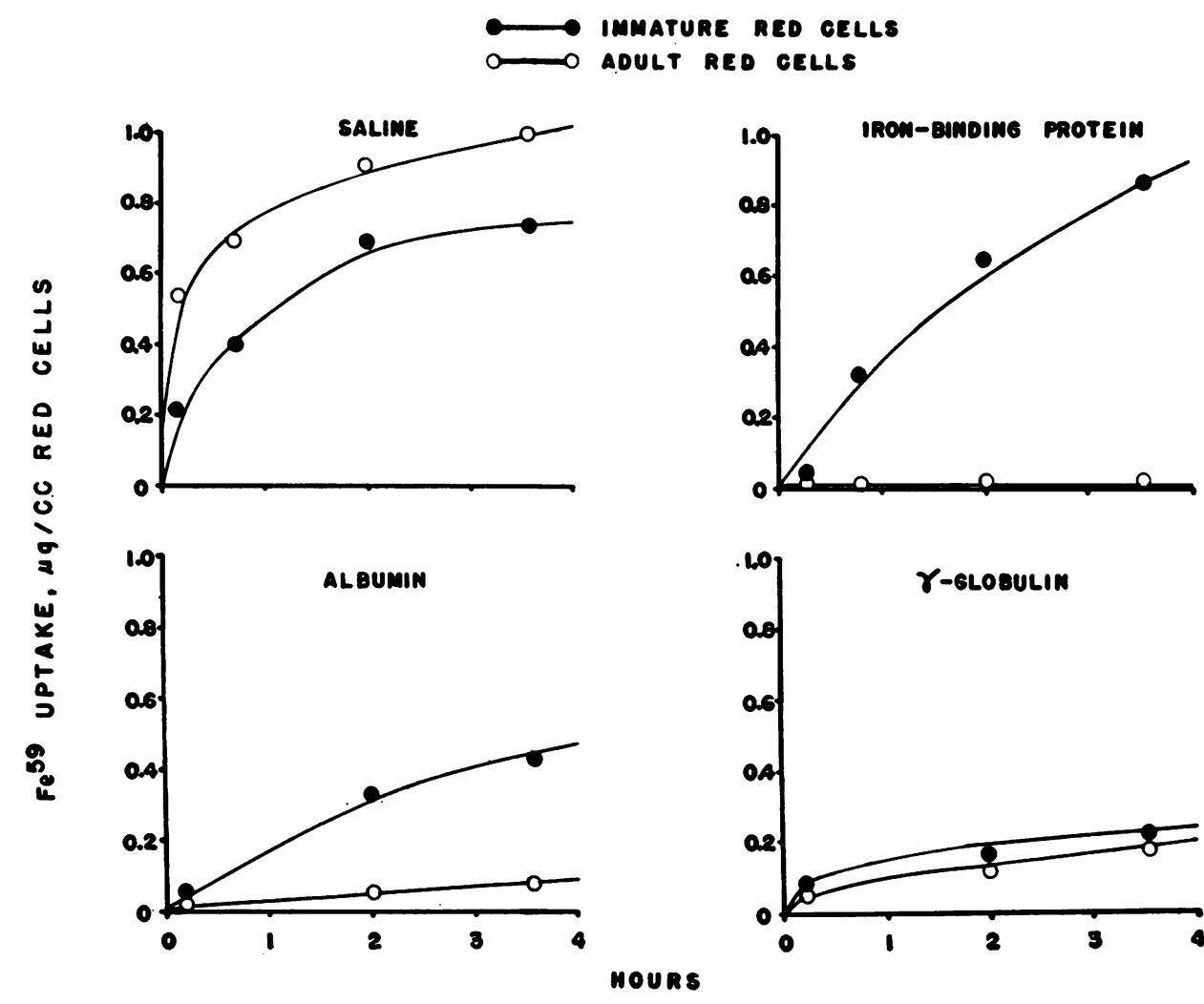

Fig. 1. The Influence of Protein Binding on the Uptake of Iron by Immature and Mature Red Cells

$\mathrm{Fe}^{\infty} \mathrm{Cl}_{3}$ was added to saline, albumin, iron-binding protein and $\gamma$-globulin solutions. After one hour at room temperature these mixtures were incubated with a washed suspension of red cells containing 31.5 per cent reticulocytes from a patient with acquired hemolytic anemia (immature red cells) and with a washed suspension of normal adult red cells, only 0.3 per cent of which were reticulocytes.

The uptake of $\mathrm{Fe}^{\mathrm{so}}$ by the washed cells after various periods of times was then measured as described under "Methods." Note the striking selectivity with which immature red cells took up $\mathrm{Fe}^{\mathrm{so}}$ from the iron-binding protein.

red cells was initially very rapid, and gradually diminished thereafter. Approximately 90 per cent of the $\mathrm{Fe}^{59}$ adsorbed by these red cells remained in the membrane fraction after water hemolysis and centrifugation at $1,000 \mathrm{G}$; and when the uptake of $\mathrm{Fe}^{59+++}$ exceeded about $5 \mu \mathrm{g}$. per ml. red cells, red cell agglutination ensued, a finding reported in more detail elsewhere (30). Siderocyte granules were not observed in such iron-coated red cells.

Although the uptake of $\mathrm{Fe}^{+++}$from saline by the reticulocytes of patients with various diseases was usually similar to the uptake by mature red cells obtained from these same patients, the $\mathrm{Fe}^{+++}$ uptake of reticulocyte-poor suspensions of red cells from patients with acquired anemia and a positive Coombs test was consistently smaller than that of reticulocyte-rich suspensions prepared from the same blood specimens (Figure 2) or of suspensions of normal mature red cells (Figure 1). In pursuance of this finding, the effect of red cell sensitization with antibodies upon $\mathrm{Fe}^{+++}$ uptake was assessed by comparing the uptake of $\mathrm{Fe}^{59}$ from $30 \mu \mathrm{M} \mathrm{Fe}^{58} \mathrm{Cl}_{3}$ in one hour by washed normal red cells and by normal cells which had been sensitized before washing with serum containing incomplete anti-D. The iron uptake of anti-D sensitized red cells was $2.18 \mu \mathrm{g}$. per $\mathrm{ml}$. red cells as compared to $3.43 \mu \mathrm{g}$. of iron per ml. of unsensitized red cells. 
The uptake of $F e^{59}$ bound to IBP by mature and immature red cells

Iron bound to IBP (as $30 \mu \mathrm{M}$, half-saturated $\mathrm{Fe}^{59}$ IBP) was not taken up by mature red cells despite incubation at $37^{\circ} \mathrm{C}$. for as long as 24 hours. However, with red cell suspensions rich in reticulocytes an appreciable transfer of iron from IBP to the cells occurred, with a slowly diminishing rate of uptake over the course of several hours of incubation (Figure 1). By contrast, iron bound to human albumin (Cohn Fraction $\mathrm{V})$, in a concentration equimolar to that of the IBP studied, was transferred to some extent to mature red cells. Although iron was preferentially taken up from albumin by reticulocyte-rich cell suspensions, the uptake by these cells was less than was the case with IBP (Figure 1). Thus, with iron bound to albumin there was less discrimination between mature and immature cells than with iron bound to IBP. When iron was bound to an equimolar concentration of human gamma globulin (Cohn Fraction II-1,2) the iron uptake by adult red cells was still greater (Figure 1) but with no discrimination between adult and immature red cells.

In contrast to free iron, iron bound to IBP $\left(\mathrm{Fe}^{59} \mathrm{IBP}\right)$ was taken up by a suspension of red cells in direct proportion to its concentration of reticulocytes (Figure 2). By extrapolation of data, assuming that iron was taken up only by reticulocytes, the quantity of iron transferred in two hours from IBP to the red cells of various patients ranged from 0.5 to $4.5 \mu \mathrm{g}$. per $\mathrm{ml}$. reticulocytes. In general the amount transferred correlated with the apparent morphologic immaturity of the reticulocytes. Also in contrast

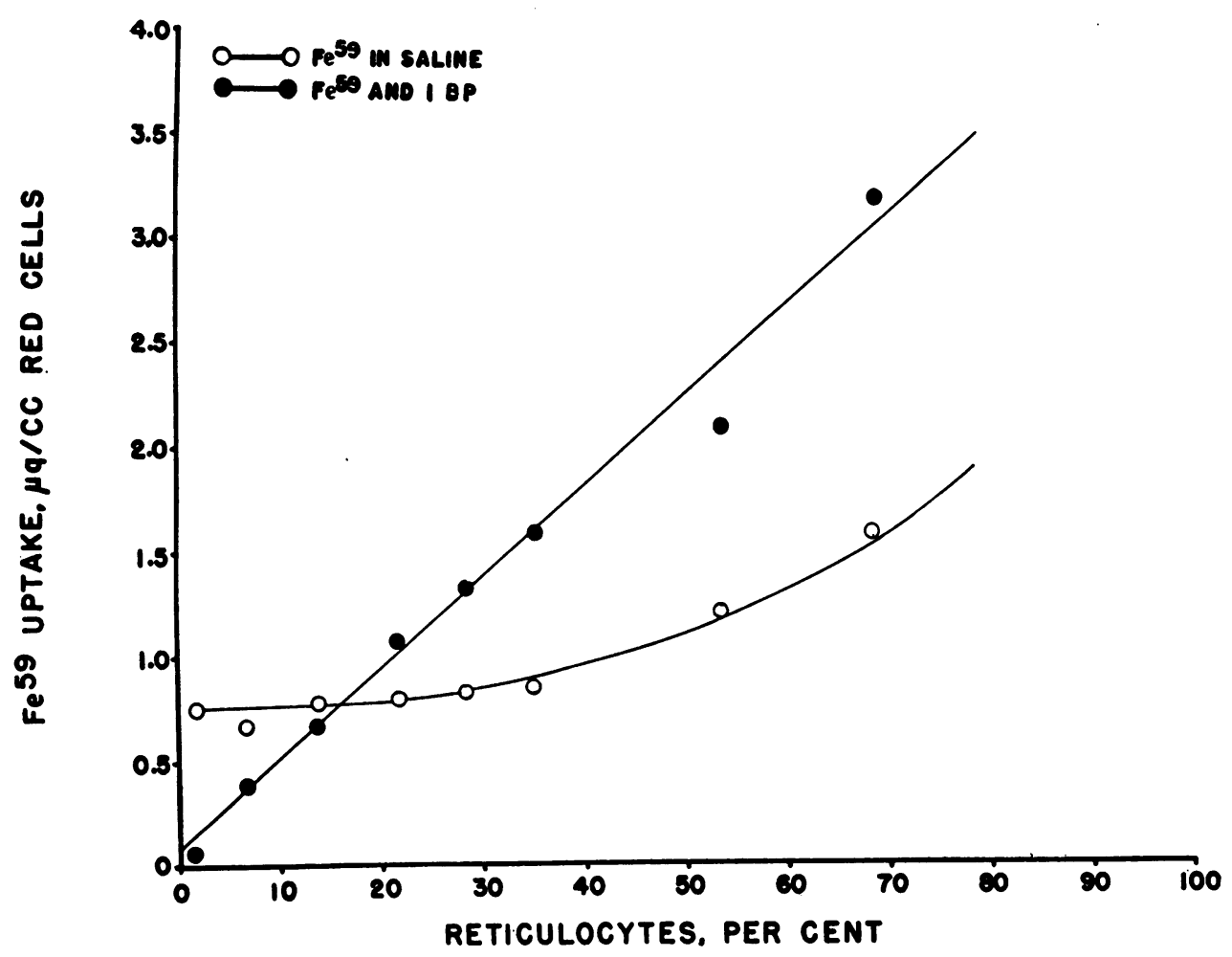

Fig. 2. The Relation Between Reticulocyte Concentration and the Uptake of Feso FROM $\mathrm{FE}^{50} \mathrm{CL}_{3}$ AND FROM $\mathrm{FE}^{50}$ IBP

Cell suspensions containing various reticulocyte concentrations were obtained by combining the top (reticulocyte-rich) and bottom (reticulocyte-poor) fractions of the centrifuged red cells of patients with acquired hemolytic anemia in different proportions. The uptake of $\mathrm{Fe}^{\mathrm{s0}}$ from $\mathrm{Fe}^{\mathrm{m}} \mathrm{IBP}$ is seen to occur in direct proportion to the reticulocyte concentration. As noted in the text, the somewhat greater uptake of $\mathrm{Fe}^{80}$ from $\mathrm{Fe}^{50} \mathrm{Cl}_{8}$ by reticulocytes than by adult cells was peculiar to patients with acquired hemolytic anemia. 


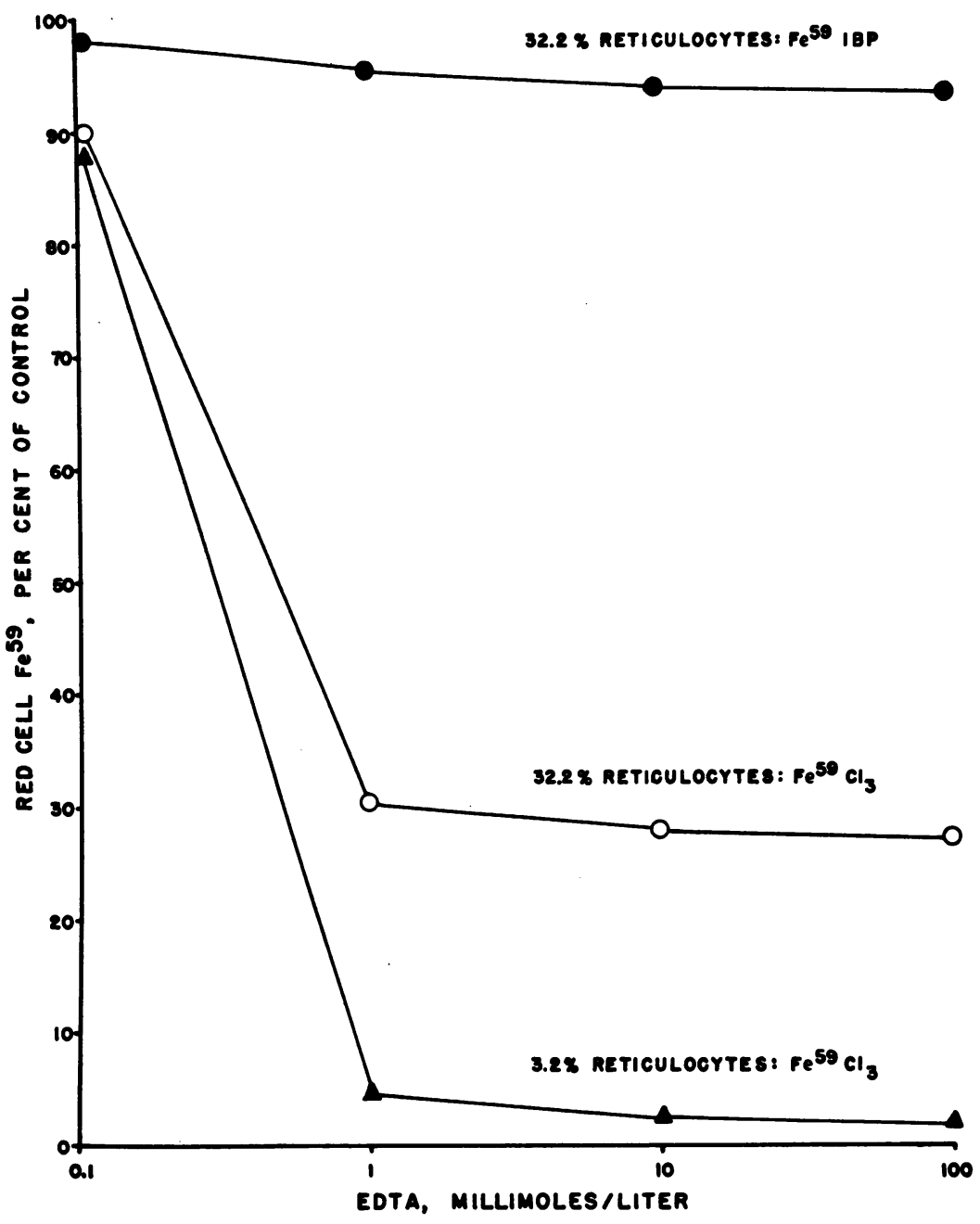

Fig. 3. The Elutability from Red Cells of Fe ${ }^{\infty}$ Taken Up IN Vitro

As indicated by the solid circles, very little of the $\mathrm{Fe}^{\mathrm{s0}}$ taken up from $\mathrm{Fe}^{\mathrm{s0}}$ IBP by a reticulocyte-rich suspension of red cells could be eluted by subsequent exposure to high concentrations of EDTA, albeit over half of the $\mathrm{Fe}^{\infty}$ was in the cell membranes. $\mathrm{Fe}^{\mathrm{s}}$ taken up from $\mathrm{Fe}^{\infty 0} \mathrm{Cl}_{3}$ by a reticulocyte-poor suspension of red cells from the same patient was almost entirely eluted by EDTA (solid triangles). $\mathrm{Fe}^{\mathrm{s0}}$ taken up from $\mathrm{Fe}^{50} \mathrm{Cl}_{3}$ by the reticulocyte-rich cell suspension was partially eluted, but almost 30 per cent of the $\mathrm{Fe}^{50}$ resisted elution by high concentrations of EDTA (empty circles), although less than 12 per cent of the $\mathrm{Fe}^{\mathrm{so}}$ had been incorporated into hemoglobin.

to the 10 per cent of $\mathrm{Fe}^{59}$ derived from $\mathrm{Fe}^{59} \mathrm{Cl}_{3}$ in saline, from 40 to 90 per cent of red cell $\mathrm{Fe}^{59}$ derived from $\mathrm{Fe}^{58}$ IBP was recoverable in the supernatant solution of water hemolysates of reticulocyte-rich blood, spun at about 1,000 G. Thus from 10 to 60 per cent of the $\mathrm{Fe}^{59}$ was associated with the reticulocyte membranes. In a representative experiment, 49.1 per cent of the $\mathrm{Fe}^{59}$ IBP taken up by reticulocytes in vitro was in the supernatant solution of the hemolysate spun at $1,000 \mathrm{G}$. A small portion (4.5 per cent of the cell uptake) of the $\mathrm{Fe}^{59}$ in the original supernate was sedimented with the ribonucleic acid-rich microsome fraction, obtained by centrifuging the supernate at $105,000 \mathrm{G}$ for 60 minutes. Another small portion of $\mathrm{Fe}^{59}$ ( 0.9 per cent of the cell uptake) was recovered in that fraction obtained by centrifuging the supernate at $26,360 \mathrm{G}$ for 20 
minutes and believed to contain the mitochondria. However, most of the nonmembrane $\mathrm{Fe}^{50}$ remained in the water-soluble phase of the lysed red cells and was incorporated into heme (see below). When a suspension of reticulocytes containing $\mathrm{Fe}^{59}$ derived from $\mathrm{Fe}^{59}$ IBP was washed free of $\mathrm{Fe}^{59}$ IBP and then incubated for up to 24 hours in native plasma or in $60 \mu \mathrm{M}$ unsaturated IBP, there was no appreciable elution of $\mathrm{Fe}^{59}$ into the medium, and during this period the proportion of $\mathrm{Fe}^{59}$ in the supernate of the hemolyzed cells to that of the whole cells (62 per cent) remained unchanged.

Iron taken up from $\mathrm{Fe}^{59}$ IBP by a red cell suspension containing 32.2 per cent reticulocytes was not appreciably eluted by subsequent exposure to EDTA in $\mathrm{pH} 6.8$ or $\mathrm{pH} 7.4$ phosphate buffer, even at concentrations as high as 0.1 M EDTA (Figure 3). This was true both of intact $\mathrm{Fe}^{59}$-labeled reticulocytes, in which approximately 55 per cent of the $\mathrm{Fe}^{58}$ was in the membrane (as determined by centrifugation of hemolysates), and of the $\mathrm{Fe}^{59}$ in cell membranes washed "free" of hemoglobin and then resuspended in EDTA. Thus the $\mathrm{Fe}^{59}$ was not unelutable simply because of incorporation into heme. On the other hand, all but 28 per cent of the iron taken up by the same red cell suspension (containing 32.2 per cent reticulocytes) from $\mathrm{Fe}^{58} \mathrm{Cl}_{3}$ in saline was eluted by EDTA. That

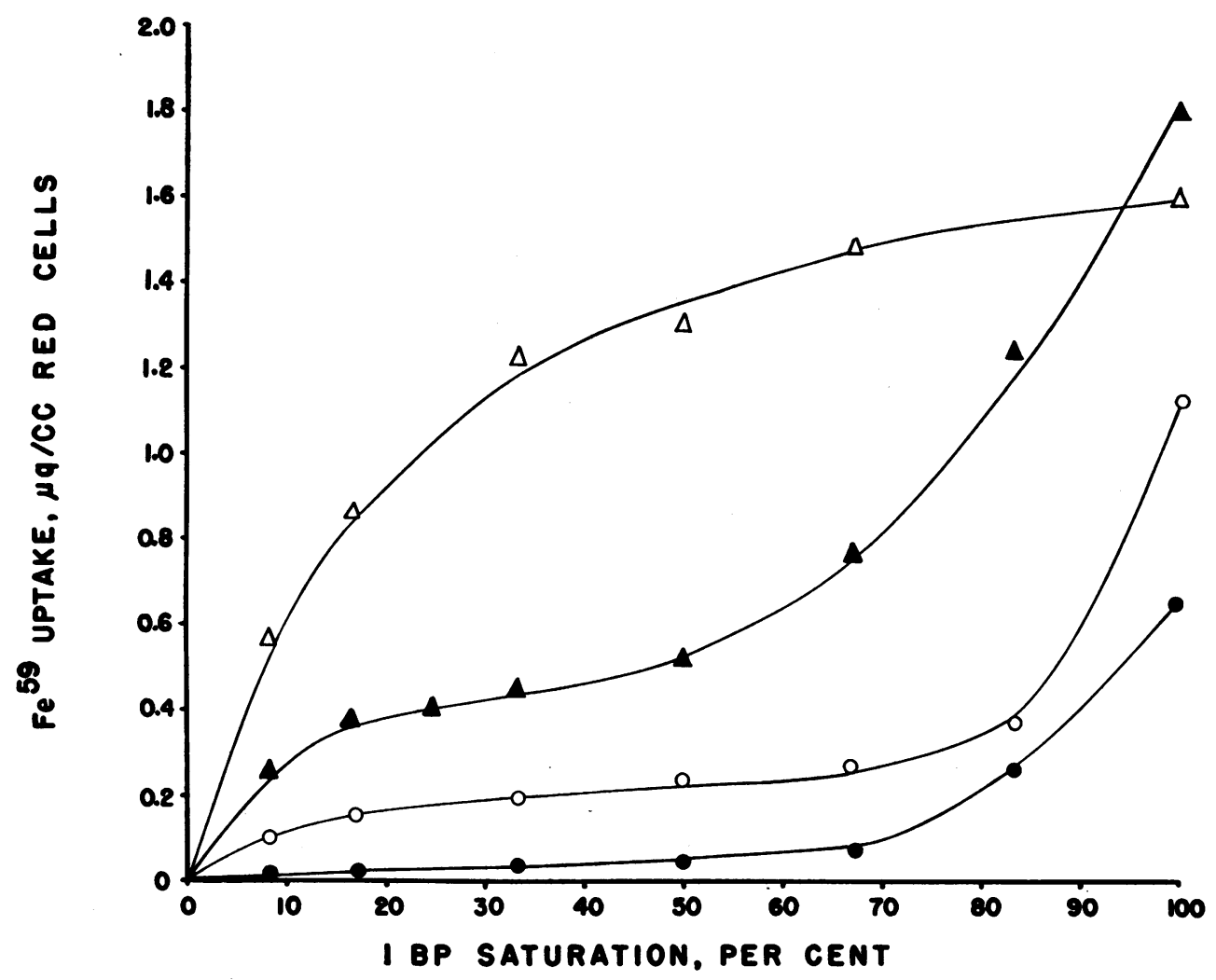

Fig. 4. The Effect of the Iron Saturation of IBP upon the Iron Uptake of Reticulocyte-Containing Red Cell Suspensions from Four Subjects

Note the tendency for $\mathrm{Fe}^{59}$ uptakes to level off at IBP saturations of over 20 to 30 per cent. If the iron uptake data above is plotted against the reciprocal of the IBP saturation (see Figure 5), straight-line relationships obtain at saturations from 0 to 50 per cent. The symbols represent red cells from subjects with the following hematologic conditions: acquired hemolytic anemia with 38.9 per cent reticulocytes (empty triangles); sickle cell anemia with 18.4 per cent reticulocytes (solid triangles); pernicious anemia during a therapeutic response with 14.9 per cent reticuloyctes (empty circles); and normal with 1.2 per cent reticulocytes (solid circles). Except with the acquired hemolytic anemia red cells a heavy "nonspecific" adsorption of iron on red cells became evident when the IBP saturation exceeded 60 to 85 per cent. 


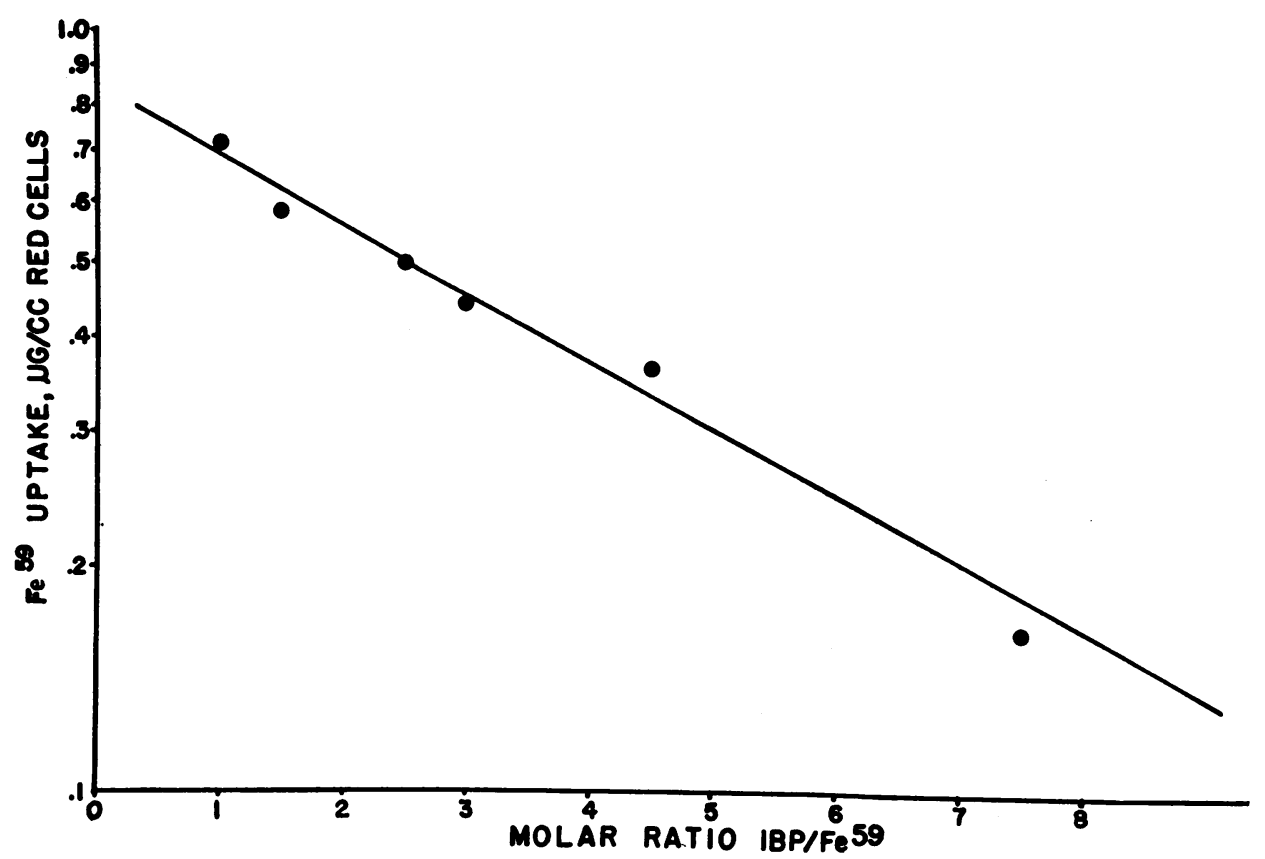

Fig. 5. The Competitive Effect of IBP on Iron Uptake by Reticulocytes

Each point represents the $\mathrm{Fe}^{50}$ uptake by equal volumes of reticulocytes incubated with constant amounts of $\mathrm{Fe}^{\mathrm{s}}$ and increasing concentrations of IBP. Since each molecule of IBP is capable of binding two atoms of iron, the points represent IBP saturations ranging from 50 to 6 per cent. The expression "molar ratio IBP $/ \mathrm{Fe}^{\mathrm{so9}}$ " is equivalent to half the reciprocal of the fractional iron saturation of IBP.

taken up by the mature red cells was almost entirely eluted by EDTA (Figure 3 ) as is true of other multivalent metals adsorbed onto red cells (30). Thus, the 28 per cent of the radioactivity that remained unelutable despite high concentrations of EDTA (Figure 3) was presumably bound to reticulocytes, but was not incorporated into heme, for 88 per cent of it was attached to the cell membranes.

In an effort to determine the chemical fraction of reticulocyte membranes to which $\mathrm{Fe}^{58}$ was bound, a reticulocyte-rich red cell suspension was incubated with autologus plasma, which had been brought to half-saturation with $\mathrm{Fe}^{59}$. These cells were then washed five times with physiologic saline, after which they were hemolyzed in three volumes of cold water and later suspended in $\mathbf{5 0}$ volumes of cold acetate buffer for 18 hours. The stroma residue which precipitated from this suspension was subjected to lipid extraction by the method of Folch and associates (31). Less than 0.1 per cent of the $\mathrm{Fe}^{59}$ taken up by the cells was recovered in the lipid extract of their membranes, whereas 34.8 per cent remained bound to the stroma residue. This $\mathrm{Fe}^{59}$-containing residue was partially soluble in 30 per cent sodium cholate. However, efforts to characterize the iron-binding component of this cholate-soluble extract by paper electrophoresis and by column chromatography were unsuccessful.

The transfer of iron from IBP to reticulocyterich suspensions of red cells was greatly affected by the degree of iron saturation of the IBP. In Figure 4 it is evident that the $\mathrm{Fe}^{59}$ uptake of reticulocytes approached a plateau when the iron saturation of the IBP exceeded 20 to 30 per cent. At iron saturations in excess of 60 to 85 per cent there was usually a sharp increase in $\mathrm{Fe}^{58}$ uptake; this appeared to be a nonspecific adsorption, for a similar sharp increase in $\mathrm{Fe}^{59}$ uptake also occurred when adult red cells were so studied. This "nonspecific" iron uptake at high iron saturation was partially diminished by increasing the bicarbonate concentration. Comparable experiments in which iron-deficient human plasma was saturated to various extents with iron revealed 
that only when the plasma iron-binding capacity was exceeded did iron "nonspecifically" attach to red cells. Even when the iron-binding capacity of plasma was exceeded, however, a majority of the excess iron was bound by other proteins. As indicated by filter paper electrophoresis and autoradiography, iron added in excess of the plasma iron-binding capacity at an alkaline $\mathrm{pH}$ was largely bound to a protein migrating midway between the alpha-1 and alpha-2 globulins; greater excesses of iron also migrated with albumin. There was no difference in this respect between normal plasma and the plasma of patients with hemochromatosis.

When the IBP was less than about 20 per cent saturated, the iron uptake of reticulocytes diminished despite an amount of iron in the system well in excess of that utilizable by the reticulocytes. The competition of IBP for iron in the presence of a given volume of reticulocytes was demonstrated either by maintaining the IBP concentration constant and varying the amount of iron added (Figure 4) or by keeping the iron concentration constant and varying the amount of IBP (Figure 5).
When to a given amount of reticulocytes various quantities of IBP of a constant $\mathrm{Fe}^{59}$ saturation ( 33.3 per cent) were added, the $\mathrm{Fe}^{59}$ uptake increased in proportion to the IBP concentration until a concentration of $160 \mu \mathrm{M}$ was exceeded (Figure 6). Thereafter, further increase in $\mathrm{Fe}^{58}$ IBP caused no further uptake.

In an effort to detect whether IBP entered reticulocytes or became attached to their surfaces, measurements were made of the IBP concentration of a preparation before and after exposure to a relatively large volume of reticulocytes. Despite removal by the reticulocytes of over 30 per cent of the iron, there was no change in the total IBP concentration.

The uptake by reticulocytes of $F e^{59}$ bound to various mammalian plasmas and to conalbumin

The uptake by human reticulocytes of iron from human plasma labeled with $1 \mu \mathrm{g}$. $\mathrm{Fe}^{58}$ per ml. plasma was similar to that from comparable concentrations and saturations of purified human IBP. As with human red cells, iron bound to $30 \mu \mathrm{M}$ human IBP was not transferred to mature rabbit or rat red cells (iron uptake $0.03 \mu \mathrm{g}$. per

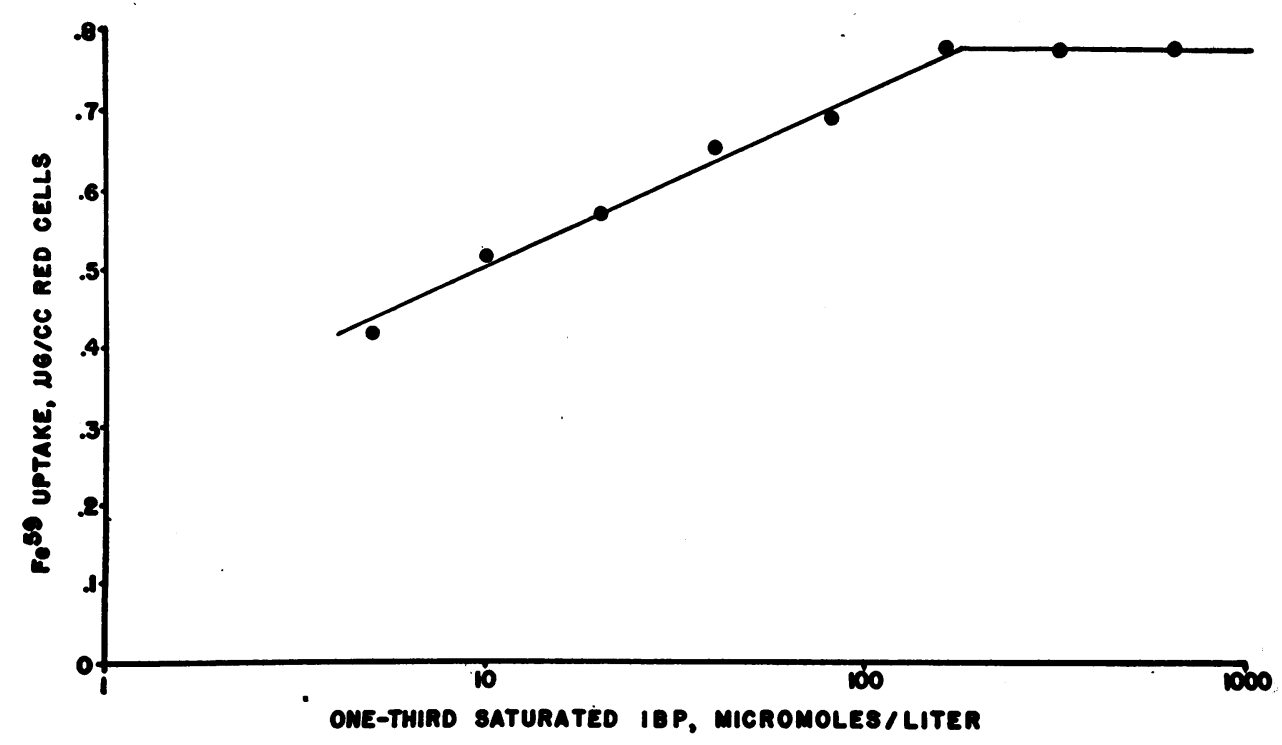

Fig. 6. The Effect of IBP Concentration on the Uptake of Iron by Reticulocytes IBP which had been 33.3 per cent saturated with $\mathrm{Fe}^{50}$ was added in increasing concentrations to a series of test tubes holding equal volumes of a suspension of red cells containing 18.0 per cent reticulocytes. Iron uptake increased in direct proportion to the $\mathrm{Fe}^{\mathrm{s}}$ IBP concentration until the latter exceeded $160 \mu \mathrm{M}\left(1.39 \mathrm{Gm}\right.$. per cent). The $\mathrm{Fe}^{\mathrm{s}}$ uptake at physiologic concentrations of IBP (approximately $27 \mu \mathrm{M}$ ) was about 77 per cent of that at $160 \mu \mathrm{M}$ concentrations of IBP. 
TABLE I

Utilization of $F e^{59}$ by human reticulocytes

\begin{tabular}{|c|c|c|c|c|c|}
\hline $\begin{array}{l}\text { Iron } \\
\text { preparation }\end{array}$ & $\mathrm{Fe}^{5}$ uptake & $\begin{array}{l}\mathrm{Fe}^{59} \text { incorporation } \\
\text { into heme }(25)\end{array}$ & $\begin{array}{l}\text { Red cell Fe } \mathrm{Fe}^{59} \\
\text { in heme }\end{array}$ & $\begin{array}{l}\mathrm{Fe}^{59} \text { incorporation } \\
\text { into hemoglobin* }\end{array}$ & $\begin{array}{l}\text { Red cell Fe } \mathrm{Fe}^{59} \\
\text { in hemoglobin }\end{array}$ \\
\hline $\begin{array}{l}\mathrm{Fe}^{59} \mathrm{IBP} \\
\mathrm{Fe}^{59} \mathrm{Cl}_{3}\end{array}$ & $\begin{array}{c}\text { mg. } / \text { ml. red cells } \\
0.24 \\
2.32\end{array}$ & $\begin{array}{c}\mu \mathrm{g} . / \mathrm{Gm} \text {. heme } \\
15.6 \\
10.5\end{array}$ & $\begin{array}{c}\% \\
76.5 \\
5.7\end{array}$ & $\begin{array}{c}\mu \mathrm{g} . / \mathrm{Gm} . \text { hemoglobin } \\
0.485 \\
0.251\end{array}$ & $\begin{array}{r}\% \\
64.6 \\
3.5\end{array}$ \\
\hline
\end{tabular}

* Determined by autoradiography as described in the text.

$\mathrm{ml}$. cells per two hours). A suspension of rabbit red cells containing 33.0 per cent reticulocytes, however, took up $0.60 \mu \mathrm{g}$. iron per ml. cells in two hours from human IBP, as compared to 1.4 $\mu \mathrm{g}$. from rabbit plasma; and a suspension of rat cells containing 14.0 per cent reticulocytes took up $0.17 \mu \mathrm{g}$. iron per ml. red cells in two hours from human IBP, as compared to $0.37 \mu \mathrm{g}$. from rat plasma. Thus in each instance iron was transferred from human IBP to heterologous reticulocytes, albeit not as readily as from the native plasma.

$\mathrm{Fe}^{59}$ bound to $30 \mu \mathrm{M}$ half-saturated conalbumin was not taken up by mature human red cells ( $0.006 \mu \mathrm{g}$. iron per $\mathrm{ml}$. red cells in two hours). However, a preparation of human red cells containing 33.5 per cent reticulocytes took up 0.535 $\mu \mathrm{g}$. iron per ml. red cells in two hours from 30 $\mu \mathrm{M}$ conalbumin, as compared to $0.613 \mu \mathrm{g}$. iron per ml. red cells in two hours from $30 \mu \mathrm{M}$ human IBP. Thus, in vitro, conalbumin was approximately as efficient an iron transport vehicle for human reticulocytes as was human IBP. Conversely, chicken (nucleated) red cells (6.2 per cent reticulocytes) took up in two hours half as much iron (0.52 $\mu \mathrm{g}$. per ml. red cells) from human IBP as they did from conalbumin (0.94 $\mu \mathrm{g}$. per ml. red cells).

The fact that chicken red cells utilized iron from conalbumin somewhat more readily than from human IBP suggested the possibility that this protein, which normally is concentrated in hens' eggs, may also function as an avian plasma transport protein. As was intimated by Jensen, Ashenbrucker, Cartwright and Wintrobe (19), the addition of radioactive iron to fresh chicken plasma (which had an iron content of $160 \mu \mathrm{g}$. per cent) caused no colorimetric change. The added $\mathrm{Fe}^{59}$ was largely dialyzable thereafter and was "nonspecifically" adsorbable by both mature and immature human red cells. However, when native chicken plasma was dialyzed at $\mathrm{pH} 5.6$ against EDTA to free it of iron, and then dialyzed free of EDTA, at a $\mathrm{pH}$ of 7.4 , this iron-free plasma was found capable of binding about 200 $\mu \mathrm{g}$. per cent of radioactive iron, as determined by dialysis experiments. Filter paper electrophoresis ( $0.05 \mathrm{M}$ barbital buffer at $\mathrm{pH} 8.6)$ and autoradioautography of chicken plasma so labeled with $\mathrm{Fe}^{59}$ revealed a specific iron-binding protein with the same mobility as that of conalbumin: midway between the $\beta$ and $\gamma$ positions.

Incorporation of $F^{59}$ into heme and into hemoglobin by human reticulocytes

In systems containing only labeled iron, IBP and washed reticulocytes suspended in saline and incubated at $37^{\circ} \mathrm{C}$. for two hours, from 20 to 50 per cent of the $\mathrm{Fe}^{59}$ taken up by the reticulocytes was recoverable in the heme fraction obtained by the method of Fischer (29). Correcting for heme lost during fractionation, it was calculated in various experiments that from 30 to 80 per cent of the reticulocyte $\mathrm{Fe}^{59}$ was incorporated into heme. Despite the higher total cell uptake of $\mathrm{Fe}^{59}$ derived from $\mathrm{Fe}^{59} \mathrm{Cl}_{3}$ than from $\mathrm{Fe}^{59} \mathrm{IBP}$, the portion of this $\mathrm{Fe}^{58}$ which was recovered with heme was far less, ranging from 2 to 12 per cent and varying in direct proportion to the percentage of reticulocytes. Presumably this is due to the fact that mature red cells, which adsorb free iron but do not synthesize heme, constituted a majority of the cells in most suspensions studied. In a single experiment the incorporation of $\mathrm{Fe}^{59}$ from $\mathrm{Fe}^{59} \mathrm{Cl}_{3}$ and from $\mathrm{Fe}^{59}$ IBP into both heme, as determined by the Fischer method, and into hemoglobin, as determined by filter paper electrophoresis and autoradiography, was compared (Table I). Both methods were in essential agreement. Note that the calculated absolute amount of $\mathrm{Fe}^{59}$ incorporated from $\mathrm{Fe}^{59} \mathrm{Cl}_{3}$ 
into the heme fraction of reticulocytes was only about two-thirds of the amount of $\mathrm{Fe}^{59}$ incorporated into the heme of reticulocytes incubated with $\mathrm{Fe}^{59}$ IBP.

Factors affecting the transfer of iron from IBP to reticulocytes

a) Temperature. The effect of temperature on iron uptake by reticulocytes was determined by incubating reticulocyte-rich red cell suspensions and $\mathrm{Fe}^{59}$-containing preparations together at certain temperatures, after these components had been separately equilibrated at these temperatures for 15 minutes. After incubation for two hours, the reaction was stopped by the addition of $\mathrm{NaCN}$ (see below), and the cells were then washed as usual. The uptake by reticulocytes of $\mathrm{Fe}^{59}$ bound to IBP was markedly temperature-dependent. As indicated in the upper part of Figure 7 , there was very little uptake at $0.5^{\circ} \mathrm{C}$.

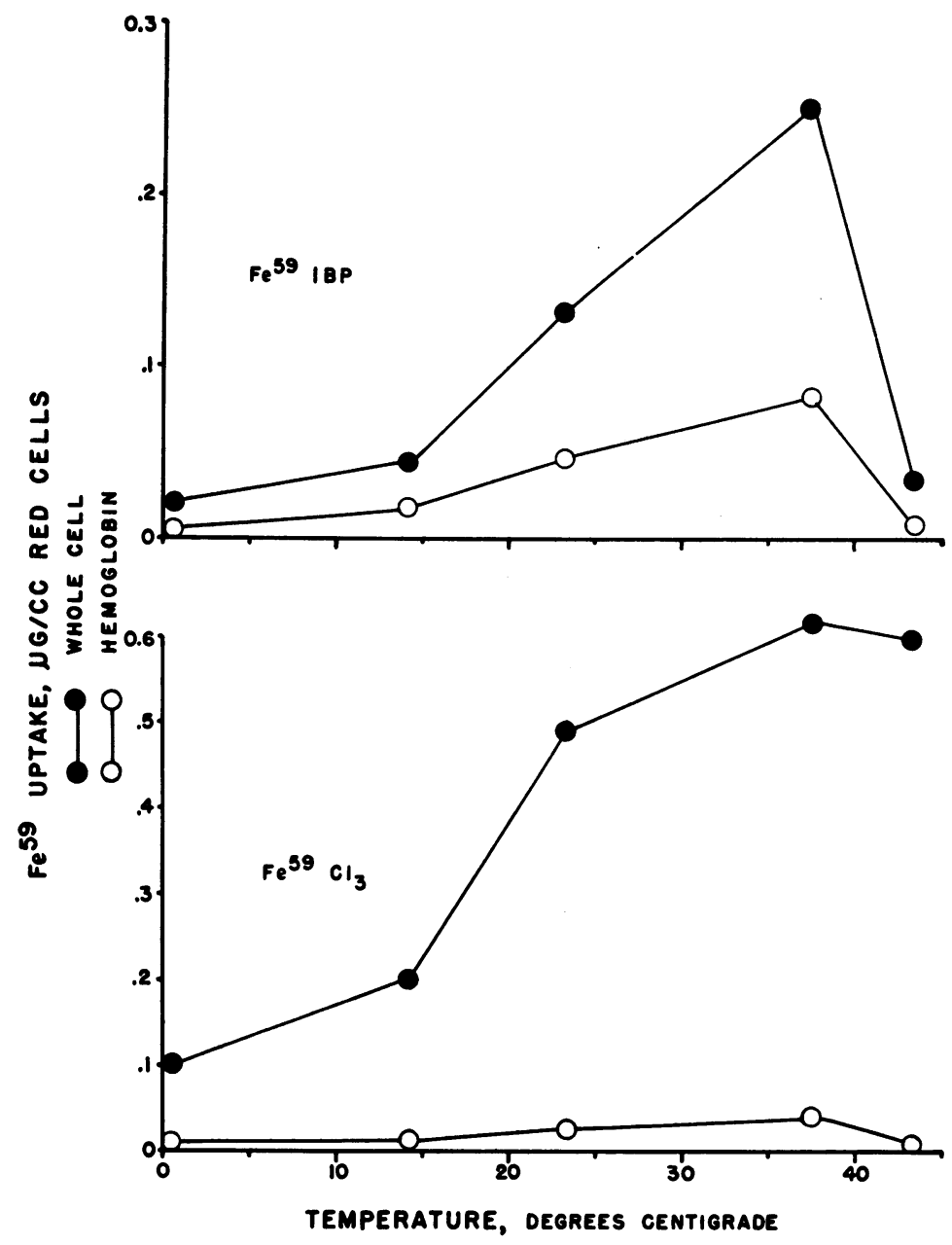

Fig. 7. The Effect of the Temperature of Incubation on the UpTAKE BY RETICULOCYTES OF $\mathrm{FE}^{60}$ FROM $\mathrm{FE}^{\infty 0}$ IBP AND FROM $\mathrm{FE}^{\infty 0} \mathrm{Cl}_{3}$

In each instance the whole cell uptake of $\mathrm{Fe}^{50}$ (solid circles) increased with increases in temperature up to $37^{\circ} \mathrm{C}$. However, $\mathrm{Fe}^{60}$ uptake from $\mathrm{Fe}^{5 \circ}$ IBP (above) was more strikingly suppressed at $0.5^{\circ} \mathrm{C}$. and at $42.5^{\circ} \mathrm{C}$. than that from $\mathrm{Fe}^{50} \mathrm{Cl}_{3}$ (below). In each study $\mathrm{Fe}^{50}$ incorporation into hemoglobin (empty circles), as determined by autoradiography, was also clearly depressed by nonphysiologic temperatures but an approximately constant proportion between hemoglobin $\mathrm{Fe}^{50}$ and whole cell $\mathrm{Fe}^{50}$ remained. 
Above $14^{\circ} \mathrm{C}$. iron uptake increased steadily to a maximum rate at $37^{\circ} \mathrm{C}$.; at $42.5^{\circ} \mathrm{C}$. the uptake was sharply inhibited. Based on these data the heat of activation $(\Delta E)$ was calculated as 12,200 calories per mole of iron. Almost identical temperature dependency was observed when $\mathrm{Fe}^{59}$ bound by plasma was incubated with reticulocytes. In parallel studies the uptake from $\mathrm{Fe}^{59} \mathrm{Cl}_{3}$ in saline both by reticulocyte-rich cell suspensions and by reticulocyte-poor cell suspensions also increased with rising temperatures, but this effect was less striking. The ratio of $\mathrm{Fe}^{59}$ uptake from $\mathrm{Fe}^{59} \mathrm{IBP}$ at $37^{\circ} \mathrm{C}$. over that at $0.5^{\circ} \mathrm{C}$. was 12.6 ; the ratio of $\mathrm{Fe}^{59}$ uptake from $\mathrm{Fe}^{59} \mathrm{Cl}_{3}$ at $37^{\circ} \mathrm{C}$. over that at $0.5^{\circ} \mathrm{C}$. was 6.2. As seen in Figure 7 there was also a fall-off of the uptake of iron from $\mathrm{Fe}^{59} \mathrm{Cl}$ at $42.5^{\circ} \mathrm{C}$., but this effect was slight compared to the sharp reduction when $\mathrm{Fe}^{59}$ IBP was employed. The incorporation of $\mathrm{Fe}^{59}$ from either $\mathrm{Fe}^{59} \mathrm{Cl}_{3}$ or $\mathrm{Fe}^{59}$ IBP into hemoglobin as determined by autoradiography showed a temperature dependence very similar to that of the whole cell uptake of $\mathrm{Fe}^{59}$ (Figure 7).

b) $p H$. The effect of $\mathrm{pH}$ on iron uptake was determined both in systems containing $\mathrm{Fe}^{59}$ IBP and in systems with $\mathrm{Fe}^{59}$-labeled plasma. Both systems were adjusted to various $\mathrm{pH}$ levels with $\mathrm{N} / 3 \mathrm{HCl}$ or $\mathrm{N} / 3 \mathrm{NaOH}$, and the final experimental $\mathrm{pH}$ level was determined after addition of the washed reticulocytes. A maximum of $\mathrm{Fe}^{59}$ uptake ranging from $\mathrm{pH} 7.2$ to $\mathrm{pH} 7.6$ was found in both systems, with sharp reductions outside of this range. Thus, there was very little iron uptake below $\mathrm{pH} 6.8$ and above $\mathrm{pH} 8.0$.

c) Oxygen tension and the state of oxidation. The effect of oxygen tension on iron uptake by reticulocytes in vitro was investigated, employing autologus plasma labeled with $\mathrm{Fe}^{59}$. After removal by centrifugation of the red cells of blood samples of patients with pernicious anemia undergoing treatment with vitamin $\mathrm{B}_{12}, \mathrm{Fe}^{59} \mathrm{Cl}_{3}$ was added to the native, hypoferremic, heparinized plasma in an amount calculated to half-saturate the iron-binding protein. Meanwhile, aliquots of the reticulocyte-rich red cells in unlabeled plasma were placed in a series of air-tight separatory funnels, each of which was equilibrated three times at one atmosphere pressure with one of the series of gas mixtures which contained various concentrations of $\mathrm{O}_{2}$ in $\mathrm{N}_{2}$ with a constant amount
TABLE II

Effect of oxygen tension on the utilization of iron by human reticulocytes

\begin{tabular}{cccccc}
\hline \hline & \multicolumn{4}{c}{ Subject } \\
\cline { 2 - 5 } $\mathrm{pO}_{2}$ & $\mathrm{~A}$ & $\mathrm{~B}$ & $\mathrm{C}$ & $\mathrm{D}$ & Average \\
\hline \multicolumn{5}{c}{$\mathrm{Fe}^{59}$} & uptake $(\mu \mathrm{g} . / \mathrm{ml}$. red cells) \\
$\mathrm{mm.Hg}$ & 0.139 & 0.227 & 0.061 & 0.068 & 0.124 \\
0 & & & & 0.083 & \\
20 & 0.176 & 0.234 & 0.075 & 0.082 & 0.142 \\
39 & 0.224 & 0.243 & 0.082 & 0.090 & 0.160 \\
81 & 0.212 & 0.252 & 0.079 & 0.089 & 0.158 \\
113 & 0.210 & 0.261 & 0.084 & 0.091 & 0.162 \\
144 & 0.210 & 0.273 & 0.086 & 0.095 & 0.166
\end{tabular}

Per cent of red cell $\mathrm{Fe}^{59}$ in "hemoglobin"*

$\begin{array}{llll}42.3 & 81.2 & 47.6 & 57.0 \\ 32.1 & 73.8 & 38.5 & 48.1 \\ 28.2 & 72.5 & 38.2 & 46.3 \\ 27.6 & 72.0 & 36.9 & 45.5 \\ 29.6 & 66.3 & 39.3 & 45.1 \\ 22.1 & 63.2 & 33.9 & 39.7\end{array}$

* Determined only presumptively in these experiments as that radioactivity remaining in the supernatant solution from centrifuged reticulocyte hemolysates.

$(4.7 \pm 0.2$ per cent $)$ of $\mathrm{CO}_{2} . \quad \mathrm{Fe}^{59}$-labeled plasma was then added to each separatory funnel and the mixtures were re-equilibrated three times with the same gas mixtures and incubated at $37^{\circ} \mathrm{C}$. for three hours. As portrayed in the upper part of Table II, the iron uptake of the whole cells (presumably reticulocytes) was least under anaerobic conditions and increased somewhat with increasing $\mathrm{O}_{2}$ tensions. On the other hand, the portion of red cell $\mathrm{Fe}^{59}$ which was present in the supernatant solution derived from hemolysates of these cells was greatest under anaerobic conditions and diminished with increasing $\mathrm{O}_{2}$ tensions.

Although it was possible to decolorize partially the iron-IBP complex with certain reducing agents such as sodium metabisulfite $(2 \times$ $\left.10^{-2} \mathrm{M}\right)$, cysteine $\left(10^{-3} \mathrm{M}\right)$ and glutathione $(2 \times$ $\left.10^{-3} \mathrm{M}\right)$, these agents did not facilitate $\mathrm{Fe}^{59}$ transfer from IBP to reticulocytes. Rather, $\mathrm{Fe}^{59}$ uptake by reticulocytes was somewhat diminished by chemical reduction, and was moderately increased by $5 \times 10^{-2} \mathrm{M} \mathrm{H}_{2} \mathrm{O}_{2}$ and by $5 \times 10^{-3}$ $\mathrm{M} \mathrm{KMnO}_{4}$.

d) Hemolysis. The effect of preliminary hemolysis of reticulocytes on their capacity to take up $\mathrm{Fe}^{59}$ from $\mathrm{Fe}^{59}$ IBP was determined by incubating $\mathrm{Fe}^{59}$ IBP with three aliquots of a reticulocyte-rich suspension of red cells, (a) in saline, 


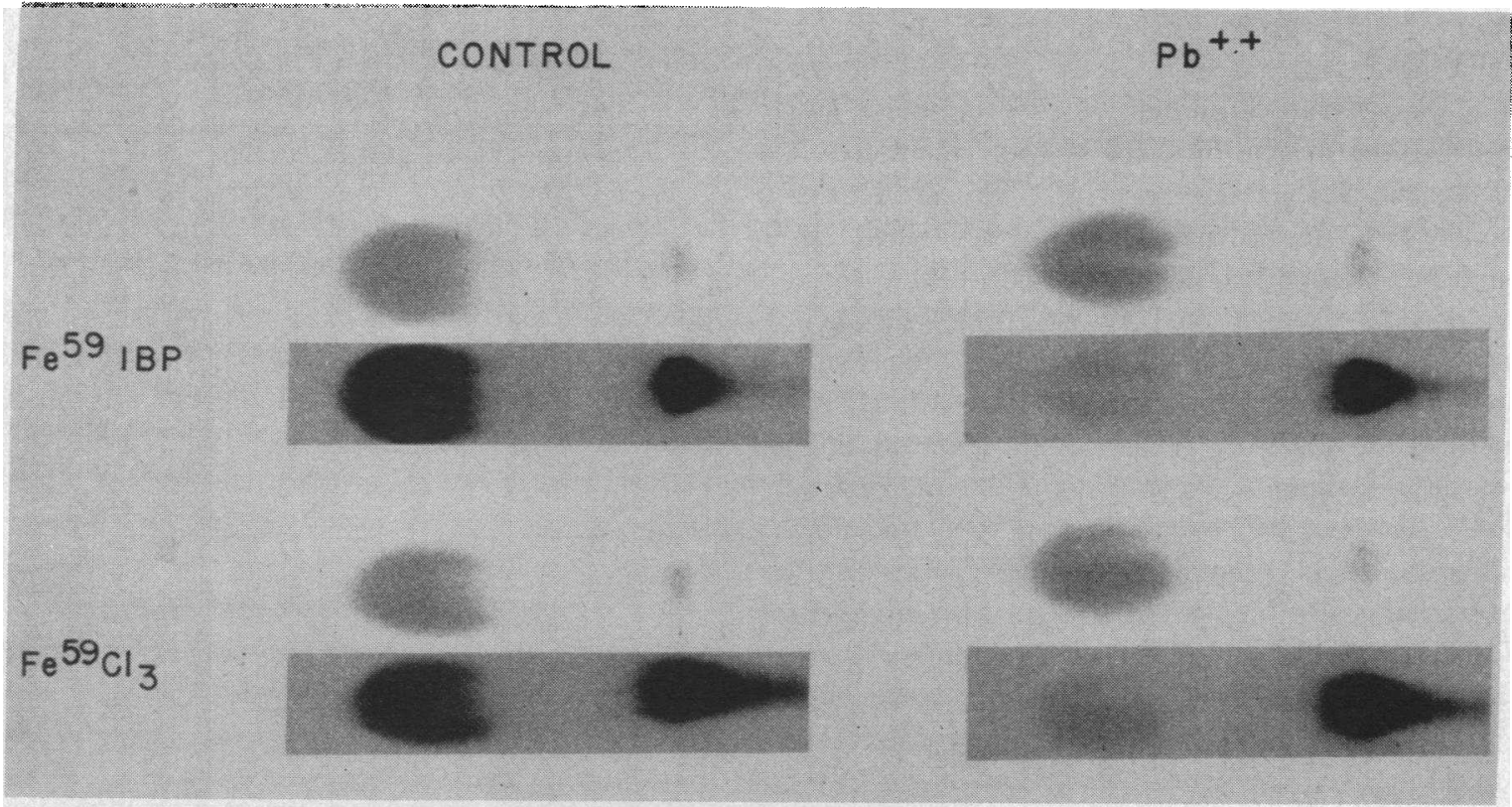

Fig. 8. The Effect of Lead on the Incorporation by Reticulocytes of Fe ${ }^{\infty}$ from Fe ${ }^{\infty 0}$ IBP and from $\mathrm{FE}^{\mathrm{s}} \mathrm{CL}_{3}$ INTO HEMOGLOBIN

After incubation with $\mathrm{Fe}^{\mathrm{s}}$, human reticulocytes were washed free of unutilized iron prior to being hemolyzed and subjected to electrophoresis at $\mathrm{pH} 6.35$ in $0.1 \mathrm{M}$ phosphate buffer. The upper (lighter) of each of the four pairs of strips is the unstained hemoglobin paper electrophoretogram. In each the heavy spot to the left represents hemoglobin migrating toward the anode, and the small spot to the right is at the origin and consists largely of cell membranes. The lower (darker) of each of the four pairs of strips is the autoradiogram of the paper strip. As compared to incubation without lead (left), reticulocytes incubated with $10^{-4} \mathrm{M} \mathrm{PbCl}_{2}$ (right) showed a marked inhibition of incorporation of $\mathrm{Fe}^{\mathrm{s}}$ into hemoglobin, whether the $\mathrm{Fe}^{\infty}$ was derived from $\mathrm{Fe} e^{\infty} \mathrm{IBP}$ or $\mathrm{Fe}^{\infty} \mathrm{Cl}_{3}$. At this concentration of lead, however, the total reticulocyte uptake of $\mathrm{Fe}^{\mathrm{so}}$ was only slightly inhibited, causing a relative accumulation of $\mathrm{Fe}^{\mathrm{se}}$ on the reticulocyte membranes. Note in the control study how much more efficiently $\mathrm{Fe}^{50}$ was incorporated into hemoglobin when derived from $\mathrm{Fe}^{\infty} \mathrm{IBP}$ than when derived from $\mathrm{Fe}^{\infty} \mathrm{Cl}_{3}$.

(b) after hemolysis with three volumes of distilled water, and (c) after hemolysis by rapid freezing and thawing. After incubation for two hours at $37^{\circ} \mathrm{C}$. the intact reticulocytes in (a) were also hemolyzed with distilled water, and the cell membranes in all tubes were then washed three times with cold physiologic saline. The $\mathrm{Fe}^{59}$ content of the membranes from the reticulocytes hemolyzed in (b) and (c) before incubation with $\mathrm{Fe}^{59}$ IBP was only 7 per cent of that of membranes from reticulocytes in (a) which were intact during the incubation period.

e) Metabolic accelerators and inhibitors. The influence of several metabolic accelerators and substrates on the transfer of $\mathrm{Fe}^{59}$ from buffered solutions of $\mathrm{Fe}^{59} \mathrm{IBP}$ to human reticulocytes was evaluated during two hour periods of incubation at $37.5^{\circ} \mathrm{C}$. Glucose in concentrations of $2 \times 10^{-2} \mathrm{M}$ increased $\mathrm{Fe}^{59}$ uptake by reticulocytes moderately, with values ranging from 110 per cent to 150 per cent of control values. Inosine $\left(5 \times 10^{-2} \mathrm{M}\right)$, glycine $\left(10^{-1}\right.$ $\mathrm{M})$, succinic acid $\left(10^{-1} \mathrm{M}\right)$, methylene blue (20 mg. per cent) and citrate $\left(10^{-1} \mathrm{M}\right)$, all in the presence of $2 \times 10^{-2} \mathrm{M}$ glucose, did not increase $\mathrm{Fe}^{59}$ uptake further, either singly or in combination.

The uptake of $\mathrm{Fe}^{59}$ from $\mathrm{Fe}^{59}$ IBP by reticulocytes was moderately depressed, but not abolished by $\mathrm{HCO}_{3}^{-}$concentrations in excess of $10^{-2} \mathrm{M}$. At given $\mathrm{HCO}_{3}-$ levels, sodium acetazoleamide at concentrations as high as $50 \mathrm{mg}$. per $\mathrm{ml}$. cells had no effect on iron uptake. Each of several "metabolic inhibitors" studied $\left(10^{-2} \mathrm{M}\right.$ sodium cyanide, $10^{-2} \mathrm{M}$ sodium fluoride, $10^{-2} \mathrm{M}$ sodium azide, $10^{-3} \mathrm{M}$ sodium arsenate and $10^{-3} \mathrm{M}$ iodoacetic acid) reduced the $\mathrm{Fe}^{59}$ uptake by reticulocytes (suspended in Krebs-Ringer phosphate so- 
lution containing glucose) to less than 20 per cent of control values. Marked inhibition of iron uptake was caused by as little as $10^{-4} \mathrm{M}$ concentrations of 2,4-dinitrophenol and $10^{-5} \mathrm{M}$ 2,4-dinitrophenylphenol. However, concentrations of fluoracetate as high as $2 \times 10^{-2} \mathrm{M}$ had no inhibitory effect.

The possibility that iron uptake was suppressed indirectly by inhibition of heme synthesis was examined by observing the effect of lead, which interferes with several stages in the synthesis of heme $(32,33)$. Although inhibited by $5 \times 10^{-4}$ concentrations of $\mathrm{Pb}^{++}$, the whole cell uptake of $\mathrm{Fe}^{59}$ by human reticulocytes during two hours at $37.5^{\circ} \mathrm{C}$. was only slightly diminished $(-20.6$ per cent) in the presence of $1 \times 10^{-4} \mathrm{M} \mathrm{Pb}^{++}$. However, the incorporation of $\mathrm{Fe}^{59}$ into hemoglobin was almost entirely prevented, as is evident in Figure 8, whether the $\mathrm{Fe}^{59}$ was derived from $\mathrm{Fe}^{59}$ IBP or from $\mathrm{Fe}^{59} \mathrm{Cl}_{3}$ in saline. Thus the amount of iron remaining in the cell membrane was increased. This pile-up of iron on the membrane was not the result of an increase in membrane hemoglobin and the increased membrane $\mathrm{Fe}^{59}$ in lead-poisoned reticulocytes was not recovered in heme extracts of the membrane.

The results of a comparable study of the effect of lead on the uptake of $\mathrm{Fe}^{59}$ from rabbit plasma by the reticulocytes of bled rabbits are presented in Table III. In this experiment a reticulocyterich suspension of washed rabbit red cells was incubated for five minutes with $10^{-4} \mathrm{M} \mathrm{PbCl}_{2}$, after which $\mathrm{Fe}^{59}$-labeled plasma was added and incubated with the cells at $37^{\circ} \mathrm{C}$. under oxygen for one hour before cell fractionation was carried out. It is evident from Table III that, although the total cell uptake of $\mathrm{Fe}^{59}$ was moderately diminished by this concentration of $\mathrm{Pb}^{++}$, there was a striking increase of $\mathrm{Fe}^{59}$ in the stromal (mem- brane) fraction of lead-poisoned cells, and, proportionately, a reduction in $\mathrm{Fe}^{59}$ in the hemoglobincontaining supernate. There was no evidence that lead caused iron to accumulate in the microsomal fraction or in the fraction believed to contain the mitochondria.

f) Metals and chelating agents. The question whether, in its transfer from IBP to reticulocytes, iron exists at any time in the free ionized state was examined by adding $\mathrm{Fe}^{59}$ IBP to each of a series of tubes containing a reticulocyte-rich suspension of red cells to which various amounts of nonradioactive $\mathrm{FeCl}_{3}$ had been added. There was no competitive inhibition of $\mathrm{Fe}^{59}$ uptake by the added ionized iron. The effect on iron uptake of several other metals known to participate in enzymic systems was also explored. Concentrations of $\mathrm{KCl}, \mathrm{MgCl}_{2}$, and $\mathrm{CaCl}_{2}$ ranging from $10^{-4}$ to $10^{-2} \mathrm{M}$ had no effect. $\mathrm{CoCl}_{2}$ concentrations of $10^{-3} \mathrm{M}$, or greater, moderately suppressed iron uptake.

More evidence that iron did not exist in the free state during transfer from IBP to reticulocytes, and that traces of nonferric metals were not involved in the reaction, was obtained by use of EDTA which competes with IBP for iron, As is shown in Figure 9, EDTA dissolved in $\mathrm{pH}$ 7.4 phosphate buffer completely blocked the uptake by red cells of $\mathrm{Fe}^{59}$ from $\mathrm{Fe}^{59} \mathrm{Cl}_{3}$ at a molar ratio of EDTA/Fe of two. EDTA was equally effective in this respect on reticulocytes (Figure 9) and on adult red cells (not shown), indicating that it did not function as an iron transfer agent. In contrast to the findings with $\mathrm{Fe}^{59} \mathrm{Cl}_{3}$, the transfer of iron from IBP to reticulocytes was not significantly affected by the presence of EDTA until the ratio of EDTA/Fe exceeded 10 ; and $\mathrm{Fe}^{59}$ uptake from $\mathrm{Fe}^{59}$ IBP was not abolished even at a ratio of EDTA/Fe of 100 , despite the fact that

TABLE III

The effect of lead on the uptake and intracellular distribution of iron in rabbit reticulocytes

\begin{tabular}{|c|c|c|c|c|c|}
\hline \multirow[b]{3}{*}{$\begin{array}{l}\text { Reticulocyte } \\
\text { suspension }\end{array}$} & \multirow[b]{3}{*}{$\begin{array}{l}\text { Whole } \\
\text { cells }\end{array}$} & \multicolumn{3}{|c|}{$\mathrm{Fe}^{5}$ activity $(\mathrm{cpm} / \mathrm{ml}$. cells $)$} & \multirow[b]{3}{*}{$\begin{array}{l}\text { Soluble } \\
\text { supernate }\end{array}$} \\
\hline & & \multicolumn{3}{|c|}{ Sediment from spun hemolysate } & \\
\hline & & $\begin{array}{l}7,000 \mathrm{G} \times 15 \mathrm{~min} . \\
\text { (Cell membrane) }\end{array}$ & $\begin{array}{c}26.000 \mathrm{G} \times 20 \mathrm{~min} . \\
\text { (Mitochondria) }\end{array}$ & $\underset{\text { (Microsomes) }}{105,000 \mathrm{G} \times 60 \mathrm{~min}}$ & \\
\hline $\begin{array}{l}\text { Control } \\
\text { Lead-poisoned } \\
\qquad\left(10^{-4} \mathrm{M} \mathrm{Pb}^{++}\right)\end{array}$ & $\begin{array}{l}446,250 \\
210,200\end{array}$ & $\begin{array}{r}23,200 \\
113,100\end{array}$ & $\begin{array}{r}800 \\
1,600\end{array}$ & $\begin{array}{l}700 \\
900\end{array}$ & $\begin{array}{r}412,200 \\
76,720\end{array}$ \\
\hline
\end{tabular}




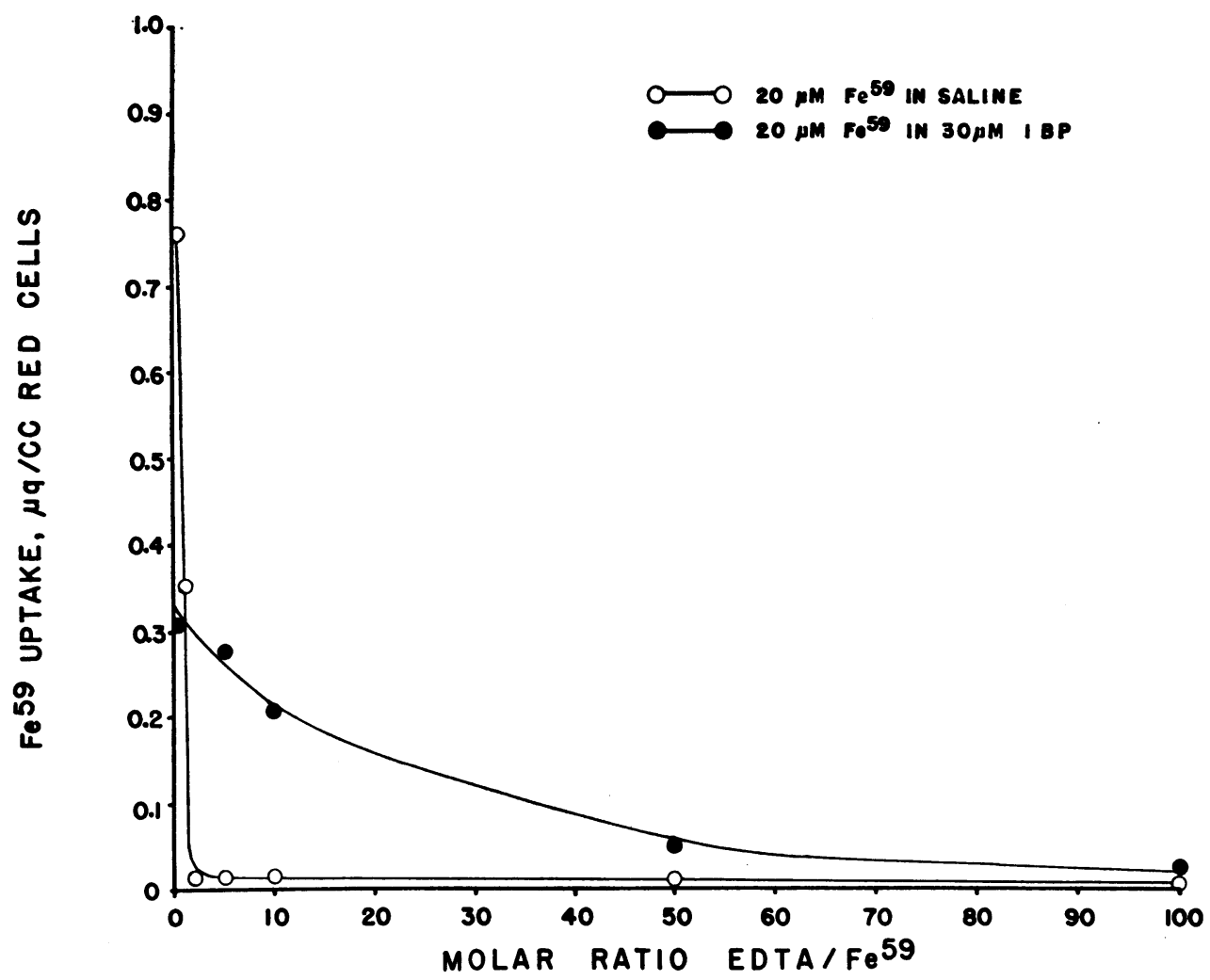

Fig. 9. The Effect of EDTA on the Uptake of Fe ${ }^{50}$ by Reticulocytes from Fe ${ }^{59}$ IBP and $\mathrm{FE}^{50} \mathrm{CL}_{3}$

With a molar ratio of EDTA/iron of two or more, iron was not taken up from $\mathrm{Fe}^{50} \mathrm{Cl}_{3}$ by reticulocytes. However, a relatively large excess of EDTA was needed to suppress the transfer of iron from $\mathrm{Fe}^{\mathrm{s} \theta}$ IBP to reticulocytes.

this amount of EDTA caused over 50 per cent dissociation of the $\mathrm{Fe}^{58}$ IBP complex as determined colorimetrically.

g) Effect of enzymatic alteration of red cell surfaces. In order to explore the hypothesis that the immature red cell membrane includes on its surface receptor sites which bind iron, the effects of certain enyzmes which alter the red cell surface were observed. Reticulocyte-rich washed red cell suspensions were incubated for one hour at $37^{\circ} \mathrm{C}$. in $\mathrm{pH} 7.6$ phosphate buffer with various concentrations of trypsin. ${ }^{7}$ These cells were then washed in phosphate buffer $(\mathrm{pH}$ 7.4) once, and in physiologic saline twice, and were then incubated, in parallel studies, with $\mathrm{Fe}^{59}$ IBP and with $\mathrm{Fe}^{59} \mathrm{Cl}_{3}$ in saline. Pretreatment of reticulocytes with as little as 0.001 per cent tryp-

\footnotetext{
7 Trypsin, crystalline (salt-free, lyophilized). Mann Research Laboratories, New York, N. Y.
}

sin (0.01 mg. per ml.) markedly suppressed their ability to take up $\mathrm{Fe}^{59}$ IBP (left portion of Figure 10). On the other hand, the adsorption of $\mathrm{Fe}^{59} \mathrm{Cl}_{3}$ by these enzyme-treated cells was unaffected. As indicated by the interrupted line in Figure 10, the uptake of iron from $\mathrm{Fe}^{59}$ IBP by trypsinized reticulocytes was consistently greater (although still markedly depressed) when glucose $(0.015 \mathrm{M})$ was included in the system during incubation of cells and $\mathrm{Fe}^{59} \mathrm{IBP}$. When reticulocytes were first trypsinized, then incubated with glucose for two hours, and finally incubated with $\mathrm{Fe}^{59}$ IBP, with two saline washings of the cells between each incubation, the effect of trypsinization upon iron uptake was again diminished but not to the extent observed when glucose was present during the incubation of cells with $\mathrm{Fe}^{59}$ IBP. The presence of iron in the medium during trypsinization did not affect the subse- 
quent inhibition of $\mathrm{Fe}^{59}$ uptake. Trypsinization of reticulocytes curtailed the subsequent uptake of $\mathrm{Fe}^{59}$ from $\mathrm{Fe}^{59}$ bound to plasma to the same extent as that bound to purified IBP. Reticulocytes, previously incubated with various concentrations of trypsin as described above, were resuspended in plasma containing $\mathrm{Fe}^{59}$ and were then incubated in Warburg flasks for three hours. During this time oxygen consumption was observed, and at the end of incubation the lactate content of the supernatant plasma specimens and the $\mathrm{Fe}^{59}$ activity of the red cell specimens were determined. Although $\mathrm{Fe}^{59}$ uptake by the reticulocytes was, once again, sharply diminished by pretreatment with 0.001 per cent, 0.01 per cent, and
0.1 per cent trypsin, these concentrations of trypsin had no effect upon either oxygen consumption or lactate production. Incubation of reticulocytes with 0.1 per cent trypsin, after these cells had taken up $\mathrm{Fe}^{59}$ from $\mathrm{Fe}^{59}$ IBP, did not cause elution of $\mathrm{Fe}^{59}$ into the medium, even though 50 per cent of the $\mathrm{Fe}^{59}$ was in the cell membranes as determined by centrifugation. Chymotrypsin ${ }^{8}$ treatment also blocked the uptake of $\mathrm{Fe}^{59}$ by reticulocytes, although it was not quite as potent in this respect as trypsin.

The effect of enzymatic destruction of the sialic acid of the reticulocyte surfaces by receptor-

8 Chymotrypsin, crystalline. Mann Research Laboratories, New York, N. Y.

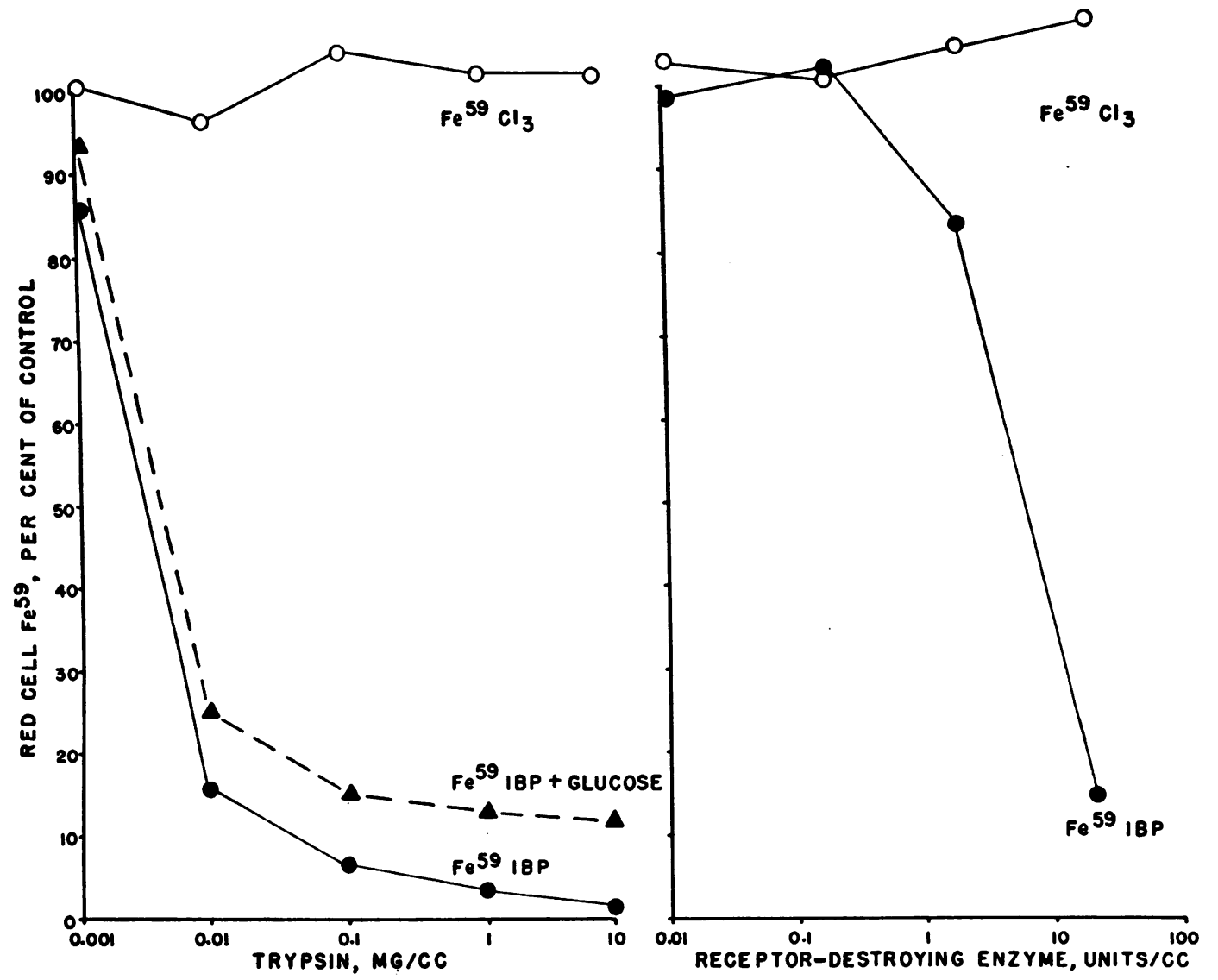

Fig. 10. The Effect of Enzymatic Alteration of Reticulocyte Surfaces on Their Subsequent Ability to TAKe UP Iron from $\mathrm{FE}^{50} \mathrm{CL}_{3}$ and $\mathrm{FE}^{\mathrm{s0}}$ IBP

Neither trypsin (left) nor receptor-destroying enzyme (RDE) (right) significantly affected the uptake by reticulocytes of $\mathrm{Fe}^{50}$ from $\mathrm{Fe}^{50} \mathrm{Cl}_{3}$. Exposure of reticulocytes to extremely low concentrations of trypsin, however, caused a marked suppression of their uptake of iron from either purified IBP (left) or from plasma (not shown). This effect of trypsin was partly reversed by the presence of glucose (interrupted line). $\mathrm{RDE}$ also diminished the subsequent uptake of reticulocytes of $\mathrm{Fe}^{\infty}$ from $\mathrm{Fe}^{\infty} \mathrm{IBP}$. However, the quantity of $\mathrm{RDE}$ preparation required to cause inhibition far exceeded that of trypsin. 


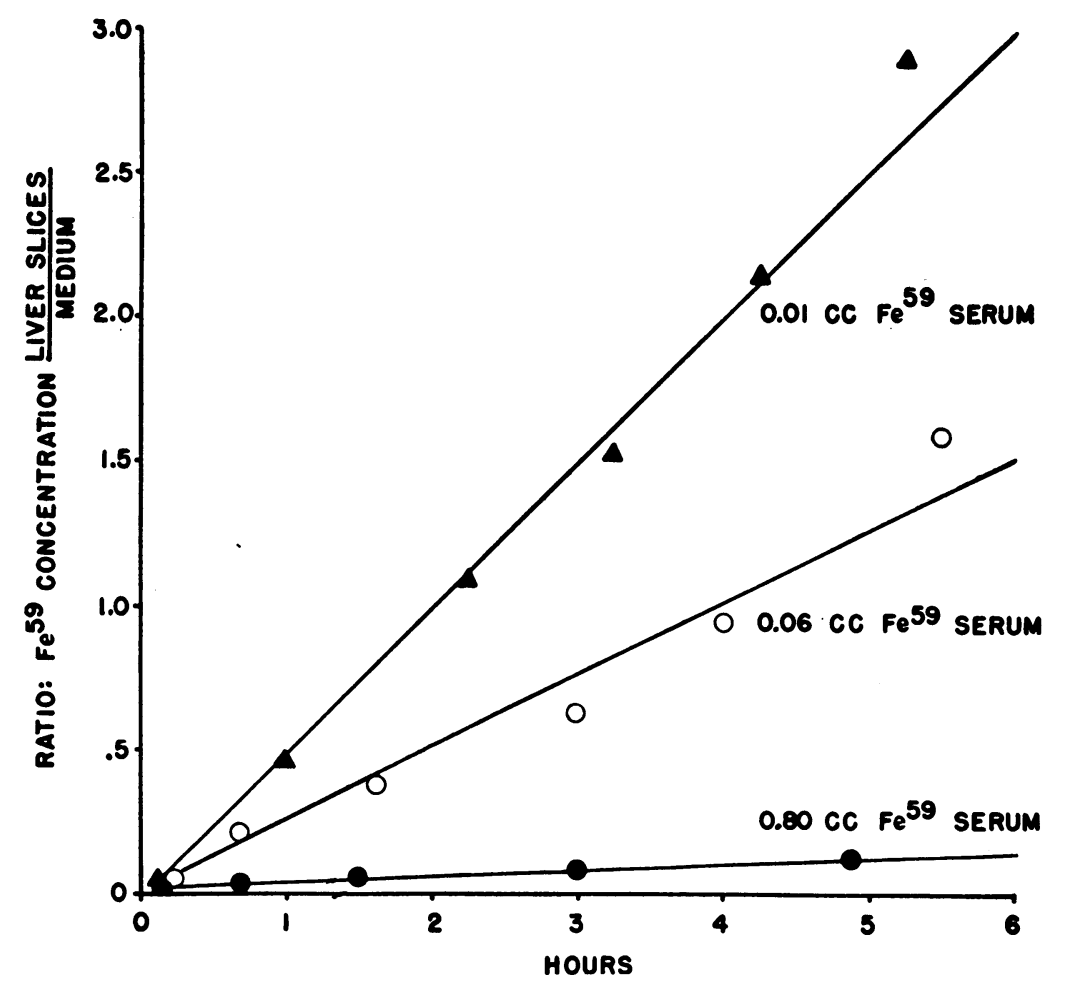

Fig. 11. The Uptake of Fe ${ }^{80}$ from Rat Serum by Rat Liver Slices as a Function of Time

Rat liver slices took up iron from rat serum in direct proportion to the period of incubation. Only when comparatively small amounts of $\mathrm{Fe}^{\text {so }}$-labeled rat serum were present, however, was an actual concentration gradient achieved. Thus when five rat liver slices were incubated with $0.01 \mathrm{ml}$. of $\mathrm{Fe}^{\mathrm{se}}$ serum for six hours (solid triangles), the concentration of $\mathrm{Fe}^{50}$ in the slices was 3.1 times that of the medium. However, when $0.8 \mathrm{ml}$. of $\mathrm{Fe}^{50}$ serum was present (solid circles) the concentration of liver slice $\mathrm{Fe}^{60}$ was only 0.15 that of the medium.

destroying enzyme (34) was investigated. Lyophilized "Receptor-Destroying Enzyme" (RDE)," derived from vibrio cholera filtrates by the method of Ada and French (35), and quantitated in the manner of Burnet, McCrea and Stone (36), was dissolved in saline, and various amounts were added to a series of tubes containing buffered saline ( $\mathrm{pH}$ 6.6) and $0.002 \mathrm{M} \mathrm{CaCl}_{2}$. Washed suspensions of reticulocyte-rich red cells were incubated with the RDE preparations, and the cellular uptake of $\mathrm{Fe}^{59}$ was then determined as described above for the experiments with trypsin. Like trypsin, RDE had no effect upon the ability of red cells to adsorb $\mathrm{Fe}^{+++}$from $\mathrm{Fe}^{59} \mathrm{Cl}_{3}$ in saline. However, at concentrations of this enzyme exceeding 1 unit per $\mathrm{ml}$,, reticulocytes

${ }^{9}$ Behringwerke, Marburg-Lahn, Federated Republic of Germany. were impaired in their ability to take up iron from $\mathrm{Fe}^{59}$ IBP (Figure 10). Nevertheless, compared to trypsin, much greater concentrations of the $\mathrm{RDE}$ preparation were required to inhibit such iron uptake. Thus, $240 \mathrm{mg}$. of RDE protein per $\mathrm{ml}$. red cells was required to suppress iron uptake to the degree effected by $0.01 \mathrm{mg}$. of trypsin per $\mathrm{ml}$. red cells. Preincubation, in an analogous manner, of reticulocyte-rich red cells and potassium periodate $\left(\mathrm{KIO}_{4}\right)$, which also inactivates sialic acid and related substances (37), caused a moderate ( 27 per cent) diminution of subsequent iron uptake by the reticulocytes from $\mathrm{Fe}^{58}$ IBP. However, the concentration of $\mathrm{KIO}_{4}$ $\left(10^{-3} \mathrm{M}\right)$ required to accomplish this inhibition was very close to that concentration $\left(2 \times 10^{-3}\right.$ M) causing hemolysis. 
Comparisons between the uptake of $F e^{59}$ by rat reticulocytes and rat liver slices

The mechanism of uptake of iron from IBP by a nonerythroid, iron-requiring tissue was explored by utilizing rat liver slices. Livers, freshly obtained from decapitated Lobund rats, were cut with a Stadie-Riggs microtome into slices weighing 50 to $100 \mathrm{mg}$. The weighed slices were then placed in groups of five in iron-free flasks containing $2 \mathrm{ml}$. of Krebs-Ringer-phosphate solution to which glucose had been added. After equilibration by agitation at $37^{\circ} \mathrm{C}$. under 95 per cent oxygen and 5 per cent $\mathrm{CO}_{2}, 1 \mathrm{ml}$. volumes of autologous rat serum which had been half-saturated with $\mathrm{Fe}^{59}$ and diluted with saline were added to each flask. Appropriately, at various time intervals, the supernate of each selected flask was decanted and saved, and its liver slices were rinsed 10 times in 50 volumes of saline. The $\mathrm{Fe}^{59}$ activities of each supernate and of the corresponding slices were then determined and expressed as the ratio of the $\mathrm{Fe}^{59}$ concentration per gram of liver slice to that per milliliter of medium.

As shown in Figure 11, rat liver slices accumulated $\mathrm{Fe}^{59}$ at a steady rate during six hours' incubation. However, in this system a concentration of $\mathrm{Fe}^{59}$ by liver slices exceeding that of the medium was only manifest after several hours when the $\mathrm{Fe}^{59}$ serum was present in relatively small amounts $(<0.1 \mathrm{ml}$. serum, half-saturated with $\mathrm{Fe}^{59}$, per flask). $\mathrm{Fe}^{59}$ accumulated by rat liver slices did not leak out if the slices were subsequently incubated with rat serum half-saturated with nonradioactive iron. On the other hand, high concentrations of human IBP $(50 \mu \mathrm{M})$ removed two-thirds of the $\mathrm{Fe}^{59}$ from rat liver slices within three hours, although this concentration of IBP failed to remove $\mathrm{Fe}^{59}$ from the stroma of rat reticulocytes. Preliminary boiling of rat

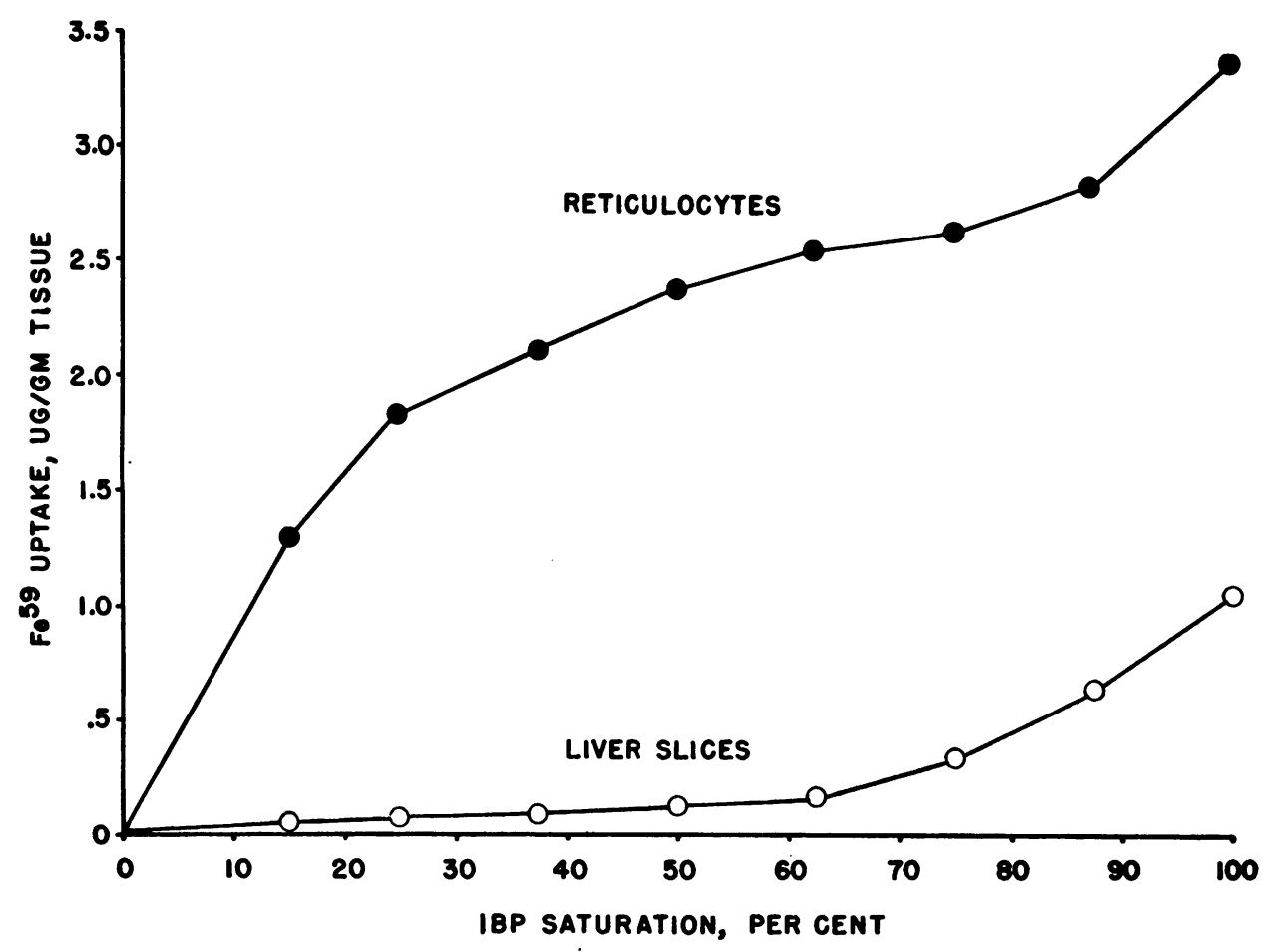

Fig. 12. The Effect of the Iron Saturation of Human IBP on the Uptake of Fe by Rat Reticulocytes and by Rat Liver Slices

As with human reticulocytes, the uptake of $\mathrm{Fe}^{\mathrm{s0}}$ from IBP by reticulocytes approached a plateau at an iron-binding protein saturation of 20 or 30 per cent, and a further sharp increase occurred at saturations above 75 per cent. In contrast rat liver slices took up comparatively small amounts of $\mathrm{Fe}^{\mathrm{so}}$ until high saturations (above 62 per cent) were reached, when $\mathrm{Fe}^{\mathrm{m}}$ adsorption sharply increased. 
liver slices for five minutes not only failed to diminish the subsequent accumulation of $\mathrm{Fe}^{58}$ from plasma by liver slices, but actually augmented it moderately. Boiling of rat reticulocytes, on the other hand, virtually abolished their capacity to take up iron.

A comparison between the uptake of iron by reticulocytes and by liver at various iron saturations of IBP was made by separately incubating autologous rat reticulocytes and liver slices, respectively, with purified human IBP which had been incubated with various amounts of $\mathrm{Fe}^{59} \mathrm{Cl}_{3}$. The reticulocytes and liver slices were taken from a rat which had been bled $20 \mathrm{ml}$. per $\mathrm{Kg}$. body weight three and four days before sacrifice. As depicted in Figure 12, rat reticulocytes resembled human reticulocytes in that the $\mathrm{Fe}^{58}$ uptake tended to level off when the iron saturation of the IBP preparation exceeded 20 to 30 per cent, only to rise further as full saturation was approached. With liver slices, on the other hand, $\mathrm{Fe}^{58}$ uptake increased slightly in a linear relationship with IBP saturation until, again, heavy deposition of $\mathrm{Fe}^{59}$ appeared at high saturations. It is apparent from this figure that at low IBP saturations the relative capacity of reticulocytes to take up iron was great, as compared to liver slices, whereas at high saturations of IBP the relative ability of liver slices to take up iron increased sharply.

The uptake of cobalt by mature and immature red cells

Cobalt, like most multivalent metals, combines with the membranes of normal washed red cells (30). Unlike iron or chromium, however, cobalt (as saline solutions of $\mathrm{Co}^{60} \mathrm{Cl}_{2}$ or $\mathrm{Co}^{60} \mathrm{Cl}_{3}$ ) was invariably taken up more avidly by reticulocytes than by adult cells. The red cells of several patients with increased reticulocytes were centrifuged and samples were removed from the top fractions (which contain most of the reticulocytes), the middle fractions, and the bottom fractions (said to contain the oldest cells [38]). In Table IV, it is apparent that the most immature red cells took up $\mathrm{Co}^{++}$most extensively, and that $\mathrm{Co}^{++}$uptake was roughly inversely proportional to cell age. Cobalt oxidized to $\mathrm{Co}^{+++}$by the presence of $10^{-2} \mathrm{M} \mathrm{H}_{2} \mathrm{O}_{2}$ was similarly accumu-
TABLE IV

The uptake of $\mathrm{Co}^{++}$by mature and immature red cells

\begin{tabular}{|c|c|c|c|c|}
\hline $\begin{array}{l}\text { Type of } \\
\text { red cells }\end{array}$ & $\begin{array}{l}\text { Centrifuged } \\
\text { fraction }\end{array}$ & $\begin{array}{c}\text { Reticulo- } \\
\text { cytes }\end{array}$ & $\underset{\mathrm{Co}^{60} \mathrm{Ci}_{2}}{\text { Conc. }}$ & $\begin{array}{l}\text { Cobalt } \\
\text { uptake }\end{array}$ \\
\hline $\begin{array}{l}\text { Pernicious } \\
\text { anemia }\end{array}$ & $\begin{array}{l}\text { Top } \\
\text { Middle } \\
\text { Bottom }\end{array}$ & $\begin{array}{c}\% \\
59.1 \\
1.6 \\
0.8\end{array}$ & $\begin{array}{c}\mu M \\
30\end{array}$ & $\begin{array}{c}\text { Mg./100 ml. } \\
\text { red cells } \\
20.48 \\
10.87 \\
5.36\end{array}$ \\
\hline $\begin{array}{l}\text { Pernicious } \\
\text { anemia }\end{array}$ & $\begin{array}{l}\text { Top } \\
\text { Middle } \\
\text { Bottom }\end{array}$ & $\begin{array}{l}8.6 \\
3.4 \\
0.4\end{array}$ & 10 & $\begin{array}{l}8.74 \\
6.55 \\
4.77\end{array}$ \\
\hline $\begin{array}{l}\text { Pernicious } \\
\text { anemia }\end{array}$ & $\begin{array}{l}\text { Top } \\
\text { Middle } \\
\text { Bottom }\end{array}$ & $\begin{array}{r}30.2 \\
12.6 \\
0.5\end{array}$ & 10 & $\begin{array}{l}5.70 \\
5.31 \\
3.87\end{array}$ \\
\hline $\begin{array}{l}\text { Acquired } \\
\text { hemolytic } \\
\text { anemia }\end{array}$ & $\begin{array}{l}\text { Top } \\
\text { Middle } \\
\text { Bottom }\end{array}$ & $\begin{array}{l}39.9 \\
26.1 \\
17.5\end{array}$ & 10 & $\begin{array}{r}13.17 \\
8.73 \\
4.60\end{array}$ \\
\hline
\end{tabular}

lated preferentially from a saline solution by immature red cells. In suspensions of reticulocytes and of adult red cells, the uptake of $\mathrm{Co}^{++++}$was 1.47 and 1.38 times, respectively, that of $\mathrm{Co}^{++}$, following the rule that the more highly charged cations are more extensively bound by red cell membranes (30).

$\mathrm{Co}^{+++}$reacts with IBP to form an amber-colored compound with a light absorptive maximum at $402 \mathrm{~m} \mu$ (6). This compound is stable as long as the cobalt is maintained in the trivalent state by a suitable oxidant, and unlike $\mathrm{Cu}^{++}$and $\mathrm{Zn}^{++}$, $\mathrm{Co}^{+++}$is not displaced from IBP by $\mathrm{Fe}^{+++}$. When $\mathrm{Co}^{60}$ IBP was incubated with adult red cells, little $\mathrm{Co}^{60}$ became attached to the red cell membrane until the IBP was more than half-saturated. When the cobalt saturation of IBP was less than 50 per cent, however, the $\mathrm{Co}^{60}$ uptake of reticulocyte-rich red cell suspensions was from 5- to 12-fold as great as that of adult red cells. It is to be noted that this was an even greater degree of preferential binding by reticulocytes than occurred with ionized cobalt. However, the uptake of $\mathrm{Co}^{60}$ from $\mathrm{Co}^{80}$ IBP by reticulocytes was considerably less than that of $\mathrm{Fe}^{58}$ from comparable preparations of $\mathrm{Fe}^{50}$ IBP, averaging about one-tenth as much.

Colorimetric interference by serum made it difficult to determine by spectrophotometry whether or not $\mathrm{Co}^{+++}$in the presence of $\mathrm{H}_{2} \mathrm{O}_{2}$ formed a colored complex with the IBP or irondeficient serum. However, with several specimens of human and of rat sera it was possible 
to show that $\mathrm{CoCl}_{3}$, added serially to plasma in a manner comparable to that employed in the determination of the serum iron-binding capacity (27), produced small increments in light absorption at a wavelength of $400 \mathrm{~m} \mu$. The erythropoietic effect of Co IBP in vivo was studied in four rats. Each was injected intravenously twice weekly for eight weeks with $2.5 \mathrm{ml}$. volumes of rat plasma which had been freshly incubated for one hour in the presence of $\mathrm{H}_{2} \mathrm{O}_{2}$ and sufficient $\mathrm{CoCl}_{2}(10 \mu \mathrm{g}$. $)$ theoretically to saturate fully the plasma IBP. No hematologic change occurred in rats injected with small amounts of cobalt in this form.

\section{DISCUSSION}

In common with most multivalent metals (30), iron in the free cationic form is adsorbed onto the membranes of either mature or immature red cells. This adsorption is injurious to red cells and may lead to their agglutination and even to hemolysis (30). Although both mature and immature red cells may take up free $\mathrm{Fe}^{+++}$, only the immature cells have the capacity to incorporate this membrane-bound iron into heme. The nonspecific capacity of red cell membranes to absorb cations such as iron presumably explains an observation by Ellis, Brandt and Thacker (39) that more iron was taken up in vitro by washed than by unwashed reticulocytes with which serum binding of iron would be in competition.

The mature red cells from patients with acquired hemolytic anemia whose red cells are agglutinable by Coombs serum, as well as red cells sensitized with incomplete anti-D antibodies, take up less free $\mathrm{Fe}^{+++}$than do normal red cells, suggesting that those chemical groups on the red cell membrane reacting with $\mathrm{Fe}^{+++}$are partially blocked by such protein "coatings."

In contrast to free cationic iron, iron bound to human serum IBP was readily utilized by immature red cells but was completely unavailable to mature red cells. In this sense the iron transporting protein of plasma is involved in a remarkable mechanism for restraining iron from reacting with, and perhaps causing injury to, cells not requiring iron while making iron available to cells which utilize iron. In comparing several substances with IBP in terms of the selectivity with which iron bound to them was utilized by reticulo- cytes and not by mature red cells, albumin was found to be much less selective, and gamma globulin and EDTA did not function in selective transport capacity at all.

The transfer of iron from IBP to reticulocytes is not species specific. Indeed, it is not even class specific, since human reticulocytes readily utilized iron bound to conalbumin, the iron-binding protein of egg white, although conalbumin does inhibit iron utilization by bacteria (9). Conversely, a recent report by Paoletti (40) indicates that avian red cells are able to utilize iron from a preparation of human IBP. These observations indicate that the structure of the protein bearing the ironchelating groups of IBP is not critical to the transfer of iron to immature red cells. On the other hand, the iron-chelating rings of IBP and of conalbumin are believed to be very similar (12).

The transfer of iron from IBP to immature red cells did not approach a maximum until the iron saturation of the protein reached 20 or 25 per cent, and nonspecific "unloading" of iron from IBP on to mature red cells began to occur at saturations above 60 per cent. It is therefore of interest that these are approximately the lower and upper limits, respectively, of normal IBP saturation in man. Thus, it is tempting to conclude that these homeostatic limits are preserved because below a saturation of 20 per cent IBP competes successfully with the marrow for iron, while above 60 per cent saturation iron is unloaded onto tissues having comparatively less affinity for iron. Experimental support for such a mechanism in the regulation of serum iron levels is provided in the comparative study of iron uptake by rat reticulocytes and rat liver slices. It is apparent in Figure 12 that at high iron saturations of IBP there is a sharp increase in the proportion of iron deposited in liver as compared to reticulocytes. The inability of liver slices, as compared to reticulocytes, to take up iron at low IBP saturations may explain the observation of Beutler (41) that rat liver cytochrome C levels are more strikingly reduced during mild or modest iron deficiency than are hemoglobin levels.

Since the total IBP concentration of serum increases during iron deficiency as well as during pregnancy (42), with consequent lowering of the percentage iron saturation, the resultant more 
active competition by the more unsaturated IBP for iron (Figure 5) might be considered disadvantageous to the immature red cells. A similar situation pertains to serum thyroxine-binding protein, the levels of which increase in myxedema and in pregnancy (43). Thus, this transport protein also appears to compete with tissues for the transported metabolite (44). It is, of course, possible that the levels of these two proteins are homeostatically adjusted primarily with respect to achieving maximum loading rather than unloading of iron and thyroxine, respectively.

The reticulocyte membrane acts in a role intermediate between the stage of plasma transport and heme synthesis, as suggested by Walsh and his associates (15), and may be considered the site of an iron-trapping mechanism. It is clear that IBP, with a biological half-life of at least 12 days (45), is not consumed during the cellular utilization of iron, which normally is half-cleared from the plasma in less than two hours. Although theoretically iron may be released from IBP by reduction, a drop in $\mathrm{pH}$, or removal of $\mathrm{HCO}_{3}^{-}$, it is also clear from the studies with EDTA reported here that, in transfer, iron is not released from IBP for any appreciable time or distance as a free ion but is directly and intimately transferred from IBP to the reticulocyte membrane. No evidence was obtained that IBP itself entered or became attached to the surfaces of the reticulocytes, although a momentary physical interaction of this sort would be hard to exclude. It is probably more reasonable to assume that IBP molecules in close proximity to the reticulocyte membrane relinquish iron to specific iron-binding receptors on the cell surface. Consistent with this explanation is the finding of a competition between IBP and reticulocytes for iron, in vitro, and the striking inability of reticulocytes to take up iron from IBP after these cells had been exposed to very small concentrations of trypsin and chymotrypsin. It is not possible to assign any specificity to this action of trypsin except to note that extremely low concentrations of trypsin were effective, and that the respiratory and glycolytic activities of the reticulocytes were unaffected by these concentrations. Although trypsin readily lyses the neuraminic acid group of substances, such as occur prominently on red cell surfaces $(34,46)$, the comparatively weak effect of "receptor-destroying enzyme" and of periodate in inhibiting iron uptake by reticulocytes indicates that the iron receptors of red cells are not identical with those red cell receptors which react with many viruses and which consist primarily of $n$-acetylneuraminic (sialic) acid $(34,47,48)$. The inability to remove more than 5 or 6 per cent of the $\mathrm{Fe}^{59}$ from reticulocyte membranes with high concentrations of IBP or EDTA is presumably attributable to the rapid incorporation of membrane iron into undissociable complexes.

It is difficult to say whether immature red cells differ from mature red cells in their ability to trap iron because immature red cells possess unique receptors or because they alone are able to metabolize membrane iron further, leaving such receptors continually unsaturated. Tishkoff, Robscheit-Robbins and Whipple have shown that the red cell stroma of dogs contains $12.4 \mu \mathrm{g}$. of iron per ml. red cells and that most of this is hemin iron (49). Human mature red cell stroma was found by Tishkoff normally to contain less than $1 \mu \mathrm{g}$. of nonhemin iron per ml. red cells, although in certain patients with erythroblastemia stromal iron levels were distinctly higher (50). The concentration of iron in the stroma of immature red cells at various stages of development is not known, but it is known by optical microscopy and, recently, by electron microscopy (21, 22) that the stroma of immature red cells, including reticulocytes, normally contains numerous iron-rich granules. Many of these granules have the aspect of ferritin (1) by electron microscopy $(21,22)$. It thus seems reasonable to suppose that in its stromal phase iron may exist in part in the form of ferritin, although, using chemical methods, we have been unable to demonstrate this. Nevertheless, it is probable that the proportion of iron localizing in the reticulocyte membranes in the experiments reported here far exceeds that which occurs in vivo. Whereas the mechanism for trapping iron remains relatively intact for several hours in vitro, it is presumed that the mechanisms for metabolizing the iron further partially break down.

Certain bacteria and smut fungi which require iron for the synthesis of cytochrome $\mathrm{C}$ and other iron-containing substances produce organic compounds with a strong affinity for iron when 
grown in an iron-deficient medium ${ }^{10}$ (51). It is believed that these organic compounds serve as carriers for the transfer of ferric ions from the medium into the bacterial cell for use in heme synthesis (51) and are analogous to the mineraldissolving organic compounds excreted by certain higher plants capable of growing on rocks (52). Neilands (51) found several compounds which, when added to simple media, served to render iron available for bacterial utilization; these included citric acid and fructose-phenylalanine. The function of the latter in this respect is of interest, since red cell membranes contain ketose-amino acids (46) and since Borsook and his associates $(53,54)$ have reported that ketoseamino acids stimulate the incorporation of amino acids into the proteins of reticulocytes when added in the presence of iron. In order to examine the possibility that ketose-amino acids participate in the transfer of iron from IBP to immature human red cells, fructose-phenylalanine, fructoseglycine and fructose-glutamine were prepared by the method of Abrams, Lowy and Borsook (55). The effect of various concentrations of these substances on $\mathrm{Fe}^{59}$ uptake from $\mathrm{Fe}^{58}$ IBP by suspensions of mature red cells, of immature red cells and of trypsinized immature red cells was then assessed. In no instance was there an acceleration of iron uptake or of iron incorporation into hemoglobin by these cells. These negative findings fail to support, but do not exclude, the possibility that such compounds, in proper steric arrangement, may function as iron-binding or ironcarrying components of the membranes of immature red cells. It is reasonable to suppose that the iron-binding substances manufactured by irondeficient bacteria and fungi are designed merely to render inorganic iron in the surrounding medium soluble and diffusible, and that the evolution in animals of cell receptors capable of directly removing iron from IBP supplanted that mechanism. Bacteria, on the other hand, ordinarily have no need for such receptors, and indeed do

\footnotetext{
10 Interestingly, the smut fungus, U. sphaerogena, becomes pale and releases iron-binding compounds into the medium when the iron concentration of the medium falls to levels similar to those in the sera of iron-deficient patients (25 $\mu \mathrm{g}$. per cent); these compounds disappear when the iron concentration is raised to that of normal sera (>100 $\mu$ g. per cent) (51).
}

not possess them, as indicated by their inability to utilize conalbumin-bound iron (9).

Since the uptake of $\mathrm{Fe}^{50}$ from $\mathrm{Fe}^{50}$ IBP was only moderately diminished by anoxia in vitro, it is improbable that iron transfer is directly dependent upon oxidative mechanisms. However, the effect of temperature upon iron uptake by reticulocytes, with striking inhibition of uptake at temperatures only a few degrees above or below $37^{\circ} \mathrm{C}$., is suggestive of an active metabolic mechanism. ${ }^{11}$ This conclusion is supported by the finding that iron uptake was stimulated by the presence of glucose and was readily inhibited by a number of agents which block intermediary carbohydrate metabolism, including cyanide, azide, fluoride, arsenate, 2,4-dinitrophenol and 2,4-dinitrophenylphenol. Immature red cells are well known to be metabolically active, and reticulocytes have been shown to possess numerous enzymes, including various elements of the tricarboxylic acid cycle (57), and these are situated at least in part in the cell membrane $(57,58)$. Since hemolysis was found here to block the transfer of $\mathrm{Fe}^{59}$ from $\mathrm{Fe}^{59}$ IBP to reticulocytes, it is of interest that Hofmann and Rapoport (59) found that the respiration of reticulocytes in vitro was considerably reduced by hemolysis, probably by disruption of the tricarboxylic acid cycle. One may reasonably conclude that the uptake of iron by immature red cells is dependent at some stage upon metabolic energy, although this energy may not be directly required for the actual transfer of iron from IBP. In its dependence upon metabolic energy, iron uptake from IBP by immature red cells differs from that by rat liver slices. Saltman, Fiskin, Bellinger and Alex (60) have reported that rat liver slices accumulate iron against a concentration gradient, and that this accumulation is unaffected by metabolic inhibitors. However, the iron employed in those studies was not bound to IBP, and the findings are more analogous to those described here with red cells in which unbound iron was used.

The fact that appropriate concentrations of

\footnotetext{
11 Although calculation of the heat of activation of a complex and incompletely-understood reaction as is involved here is very crude, the value for heat of activation calculated from the data in Figure 6 is within the range encountered in "active metabolic" or "enzymatic" reactions (56).
} 
lead block iron incorporation into the hemoglobin of reticulocytes without blocking the cellular uptake of iron from IBP indicates that the rate of transfer of iron from IBP is not directly dependent upon the rate of heme synthesis. Furthermore, these studies indicate that under these conditions lead-poisoned reticulocytes tend to accumulate nonhemoglobin iron on the cell membranes. Direct electron-microscopic evidence of iron accumulation in the stroma of immature red cells in lead poisoning has recently been reported by Bessis and Breton-Gorius (61). The finding here that blocking heme synthesis with lead caused an accumulation of iron in the reticulocyte membrane rather than in the water-soluble phase of the cell interior also indicates that, whereas the uptake of iron by the immature red cells may not be dependent upon heme synthesis, the release of iron from the membrane into the cell interior may be so dependent.

The failure of anoxia to stimulate iron uptake by reticulocytes in vitro (indeed its mild inhibitory effect) is in accord with observations of others that the maturation of immature red cells (62) and their incorporation of iron into heme (63) are somewhat inhibited, rather than stimulated, by anoxia. Thus, in terms of the ability of immature red cells to take up iron, to incorporate iron into heme and to mature morphologically, there is no evidence of a direct anoxic stimulus to red cell metabolism. The possibility that the rate of uptake of iron from IBP by reticulocytes in vitro is influenced by the presence of a plasma erythropoietic factor seems theoretically remote, since, in rabbits, this factor appears to act by stimulating cell division rather than the rate of maturation or hemoglobin metabolism (64). Indeed, it is characteristic of the active erythropoietic response to acute anoxia that the increase of red cells exceeds that of hemoglobin. Nevertheless, in an attempt to explore this possibility, the uptake by rabbit reticulocytes of $\mathrm{Fe}^{58}$ bound to rabbit plasma was measured in the presence of large volumes of plasma drawn before, and two days after, strenuous bleeding of the same rabbits. As determined by the $\mathrm{Fe}^{59}$ uptake and measurement of the iron content of the plasmas, there was no difference in the iron uptake by reticulocytes in the presence of "anemic" plasma as compared to "nonanemic" plasma.
To recapitulate the above, it is suggested that the utilization of iron by immature red cells can be separated into three phases: 1) Iron bound to IBP is transferred by competitive binding to specific receptors on the cell surface. These receptors may be effaced by certain proteolytic enzymes. 2) The functioning of these receptors is dependent upon metabolic energy, possibly for synthesizing receptors or for facilitating the release of iron from the receptors into the cell interior. This phase may be blocked by various inhibitors of oxidative metabolism. 3) Iron is then incorporated into hemoglobin, presumably under the control of the microsomes and mitochondria of the cytoplasmic reticulum. ${ }^{12}$ This stage may be blocked by low concentrations of lead.

It is of great interest that trivalent cobalt is bound by IBP in a manner comparable to iron. Cobalt, like iron, is capable of forming reversible combinations with molecular oxygen, when in the cobaltous state and linked to histidine (66). Its position in the porphyrin ring of the vitamin $\mathrm{B}_{12}$ molecule is analogous to that of iron in heme. Finally, it has the unique but still obscure capacity to stimulate erythropoiesis. It was found possible to substitute cobalt for iron in the interaction between IBP and the reticulocyte surface. However, the highly oxidant milieu needed for chelation of cobalt by IBP probably does not exist physiologically. Nor was it possible to produce polycythemia in rats repeatedly given cobalt combined with rat IBP in vitro. Finally, the fact that free $\mathrm{Co}^{++}$, unlike iron and chromium, is itself taken up by immature red cells with greater avidity than by adult red cells may be more pertinent to the mechanism of cobalt polycythemia than the reactions between cobalt and IBP.

\section{SUMMARY}

Iron bound to purified human iron-binding protein (IBP) or to conalbumin, the iron-binding

12 Although the nucleated red cells of birds have been widely employed in studies of heme synthesis, it has been clear for some time that the basophilic reticulum of the cytoplasm of immature red cells, not the nucleus, is the sine quo non of hemoglobin formation (65). As shown by Jensen and his associates (19) suspensions of avian red cells synthesize hemoglobin in vitro only in proportion to the concentration of reticulum-containing cells. 
protein of egg white and of avian plasma, is readily and preferentially transferred to immature, but not to mature, mammalian red cells. Iron transfer is dependent upon the extent of saturation of IBP, and there exists a competition for iron between IBP and iron-binding receptors on the reticulocyte membrane. These cellular receptors are destroyed by certain proteolytic enzymes. Iron appears to be directly transferred to these receptors without existing in a free form; and iron once bound to reticulocyte membranes is not exchangeable with free iron and cannot be eluted with high concentrations of IBP or of ethylenediaminetetraacetic acid (EDTA).

The transfer of IBP-iron to immature red cells, unlike the adsorption of free iron, is related to metabolic energy-producing processes. Thus, it is accelerated by glucose and oxygen and is diminished or blocked by low concentrations of metabolic inhibitors, by nonphysiologic temperatures and by hemolysis. The uptake of iron is not primarily linked to heme synthesis. Appropriate concentrations of $\mathrm{Pb}^{++}$blocked iron incorporation into heme by reticulocytes without reducing iron transfer, thus causing a pile-up of iron on the cell membranes.

Unlike reticulocytes, rat liver slices take up iron in appreciable amounts only at high IBP saturations. The transfer of iron from IBP to liver slices is not dependent upon metabolic energy and iron accumulated by liver slices can be eluted with unsaturated IBP.

Although free iron is usually bound equally by mature and immature red cells, free cobalt is more avidly bound by the immature cells. Trivalent cobalt, which forms colored chelates with purified IBP as does iron, also is bound by the IBP of whole plasma. Cobalt bound to IBP can, to a limited extent, be transferred preferentially to reticulocytes. However, the combination of $\mathrm{Co}^{+++}$and IBP probably does not occur under physiologic conditions and is probably not involved in the induction of cobalt polycythemia.

\section{REFERENCES}

1. Farrant, J. L. An electron microscopic study of ferritin. Biochim. biophys. Acta 1954, 13, 569.

2. Granick, S. Iron metabolism. Bull. N. Y. Acad. Med. 1954, 30, 81.
3. Mazur, A., Baez, S., and Shorr, E. The mechanism of iron release from ferritin as related to its biological properties. J. biol. Chem. 1955, 213, 147.

4. Holmberg, C. G., and Laurell, C. B. Investigations in serum copper. I. Nature of serum copper to the iron-binding protein in human serum. Acta chem. scand. 1947, 1, 944.

5. Surgenor, D. M., Koechlin, B. A., and Strong, L. E. Chemical, clinical and immunological studies on the products of human plasma fractionation. XXXVII. The metal-combining globulin of human plasma. J. clin. Invest. 1949, 28, 73.

6. Inman, J. K. Studies on human $\beta_{1}$-metal-combining protein. Thesis presented to the Division of Medical Sciences, Harvard University, 1956.

7. Schade, A. L., Reinhart, R. W., and Levy, H. Carbon dioxide and oxygen in complex formation with iron and siderophilin, the iron-binding component of human plasma $(1,2,3)$. Arch. Biochem. 1949, 20, 170.

8. Koechlin, B. A. Preparation and properties of serum and plasma proteins. XXVIII. The $\beta_{1}$-metalcombining protein of human plasma. J. Amer. chem. Soc. 1952, 74, 2649.

9. Schade, A. L., and Caroline, L. Raw hen egg white and the role of iron in growth inhibition of Shigella dysenteriae, Staphylococcus aureus, Escherichia coli and Saccharomyces cerevisiae. Science 1944, $100,14$.

10. Schade, A. L., and Caroline, L. An iron-binding component in human blood plasma. Science 1946, 104, 340.

11. Warner, R. C., and Weber, I. The metal combining properties of conalbumin. J. Amer. chem. Soc. 1953, 75, 5094.

12. Warner, R. C. The metal chelate compounds of proteins. Trans. N. Y. Acad. Sci. 1954, 16, 182.

13. London, I. M., Shemin, D., and Rittenberg, D. The in vitro synthesis of heme in the human red blood cell of sickle cell anemia. J. biol. Chem. 1948, 173, 797.

14. Shemin, D., London, I. M., and Rittenberg, D. The in vitro synthesis of heme from glycine by the nucleated red blood cell. J. biol. Chem. 1948, 173, 799.

15. Walsh, R. J., Thomas, E. D., Chow, S. K., Fluharty, R. G., and Finch, C. A. Iron metabolism: Heme synthesis in vitro by immature erythrocytes. Science 1949, 110, 396.

16. London, I. M., Shemin, D., and Rittenberg, D. Synthesis of heme in vitro by the immature nonnucleated mammalian erythrocyte. J. biol. Chem. 1950, 183, 749.

17. Sharpe, L. M., Krishman, P. S., and Klein, J. R. Uptake by duck erythrocytes of iron added to blood. Arch. Biochem. 1952, 35, 409.

18. London, I. M., and Yamasaki, M. Heme synthesis in non-intact mammalian and avian erythrocytes. Fed. Proc. 1952, 11, 250. 
19. Jensen, W. N., Ashenbrucker, H., Cartwright, G. E., and Wintrobe, M. M. The uptake in vitro of radioactive iron by avian erythrocytes. J. Lab. clin. Med. 1953, 42, 833.

20. Goldberg, A., Ashenbrucker, H., Cartwright, G. E., and Wintrobe, M. M. Studies on the biosynthesis of heme in vitro by avian erythrocytes. Blood 1956, $11,821$.

21. Bessis, M. C., and Breton-Gorius, J. Iron particles in normal erythroblasts and normal and pathological erythrocytes. J. biophys. biochem. Cytol. 1957, 3, 503.

22. Bessis, M., and Breton-Gorius, J. Le cycle du fer dans l'organisme révélé par le microscope électronique. Sem. Hôp. Path. et Biol. 1957, No. XIX, 2173. (Ann. Rech. méd. 1957, No. 8, 829.)

23. Jandl, J. H., Inman, J. K., and Simmons, R. L. Transfer of iron and cobalt from serum iron-binding protein to human reticulocytes. Clin. Res. Proc. 1957, 5, 144.

24. Inman, J. K. Preparation of crystalline beta ${ }_{1}-$ metal- $^{-}$ combining protein in Proc. 10th Conference on the Plasma Proteins and Cellular Elements of the Blood, Jan. 5-6, 1956, sponsored by the Protein Foundation, Inc., Cambridge, Mass., p. 46.

25. Bothwell, T. H., Hurtado, A. V., Donohue, D. M., and Finch, C. A. Erythrokinetics. IV. The plasma iron turnover as a measure of erythropoiesis. Blood 1957, 12, 409.

26. Ham, T. H. A Syllabus of Laboratory Examinations in Clinical Diagnosis. Cambridge, Mass., Harvard University Press, 1950.

27. Rath, C. E., and Finch, C. A. Chemical, clinical, and immunological studies on the products of human plasma fractionation. XXXVIII. Serum iron transport. Measurement of iron binding capacity of serum in man. J. clin. Invest. 1949, 28, 79.

28. Kitzes, G., Elvehjem, C. A., and Schuette, H. A. The determination of blood plasma iron. J. biol. Chem. 1944, 155, 653.

29. Fischer, H. Hemin in Organic Synthesis, E. C. Horning, Ed. New York, John Wiley and Sons, Inc., 1955 , coll. vol. 3 , pp. 442-43.

30. Jandl, J. H., and Simmons, R. L. The agglutination and sensitization of red cells by metallic cations: Interactions between multivalent metals and the red-cell membrane. Brit. J. Haemat. 1957, 3, 19.

31. Folch, J., Ascoli, I., Lees, M., Meath, J. A., and LeBaron, F. N. Preparation of lipide extracts from brain tissue. J. biol. Chem. 1951, 191, 833.

32. Watson, C. J. The erythrocyte coproporphyrin. Arch. intern. Med. 1950, 86, 797.

33. Eriksen, L. Lead intoxication. I. The effect of lead on the in vitro biosynthesis of heme and free erythrocyte porphyrins. Scand. J. clin. Lab. Invest. $1955,7,80$.

34. Klenk, E., and Lempfrid, $H$. Utber die Natur der Zellreceptoren für das Influenza-virus. Z. physiol. Chem. 1957, 307, 278.
35. Ada, G. L., and French, E. L. Purification of the receptor destroying enzyme of V. cholerae. Aust. J. Sci. 1950, 13, 82.

36. Burnet, F. M., McCrea, J. F., and Stone, J. D. Modification of human red cells by virus action; receptor gradient for virus action in human red cells. Brit. J. exp. Path. 1946, 27, 228.

37. Burnet, F. M. Principles of Animal Virology. New York, Academic Press Inc., 1955.

38. Borun, E. R., Figueroa, W. G., and Perry, S. M. The distribution of $\mathrm{Fe}^{\infty}$ tagged human erythrocytes in centrifuged specimens as a function of cell age. J. clin. Invest. 1957, 36, 676.

39. Ellis, G. H., Brandt, C. S., and Thacker, E. J. Factors influencing the uptake of iron by blood and by bone marrow cells in vitro. Science 1954, 119, 94.

40. Paoletti, C. Rôle des $\beta$-globulines plasmatiques dans le transport du fer utilisé par les cellules érythroformatrices. C. R. Acad. Sci. (Paris) 1957, 245, 377.

41. Beutler, E. Iron enzymes in iron deficiency. I. Cytochrome C. Amer. J. med. Sci. 1957, 234, 517.

42. Laurell, C. B. Studies on the transportation and metabolism of iron in the body with special reference to the iron-binding component in human plasma. Acta physiol. scand. 1947, 14, Suppl. 46, 1.

43. Dowling, J. T., Freinkel, N., and Ingbar, S. H. Thyroxine-binding by sera of pregnant women, newborn infants, and women with spontaneous abortion. J. clin. Invest. 1956, 35, 1263.

44. Freinkel, N., Ingbar, S. H., and Dowling, J. T. The influence of extracellular thyroxine-binding protein upon the accumulation of thyroxine by tissue slices. J. clin. Invest. 1957, 36, 25.

45. Gitlin, D., Janeway, C. A., and Farr, L. E. Studies on the metabolism of plasma proteins in the nephrotic syndrome. I. Albumin, $\gamma$-globulin and iron-binding globulin. J. clin. Invest. 1956, 35, 44.

46. Yamakawa, T., and Suzuki, S. The chemistry of the lipids of posthemolytic residue or stroma of erythrocytes. II. On the structure of hemataminic acid. J. Biochem. (Tokyo) 1952, 39, 175.

47. Gottschalk, A. Neuraminic acid; the functional group of some biologically active mucoproteins. Yale J. Biol. Med. 1956, 28, 525.

48. Howe, C., Rose, H. M., and Schneider, L. Enzymic action of influenza virus on human erythrocyte stroma components. Proc. Soc. exp. Biol. (N. Y.) 1957, 96, 88.

49. Tishkoff, G. H., Robscheit-Robbins, F. S., and Whipple, G. H. Red cell stroma in dogs. Variations in the stroma protein and lipid fractions related to experimental conditions. Blood 1953, 8, 459.

50. Tishkoff, G. H. Personal communication.

51. Neilands, J. B. Some aspects of microbial iron metabolism. Bact. Rev. 1957, 21, 101.

52. Hutner, S. H., Provasoli, L., Schatz, H., and Haskins, C. P. Some approaches to the study of the role 
of metals in the metabolism of microorganisms. Proc. Amer. phil. Soc. 1950, 94, 152.

53. Borsook, H., Abrams, A., and Lowy, P. H. Fructose-amino acids in liver: Stimuli of amino acid incorporation in vitro. J. biol. Chem. 1955, 215, 111.

54. Kruh, J., and Borsook, H. Hemoglobin synthesis in rabbit reticulocytes in vitro. J. biol. Chem. 1956, 220, 905.

55. Abrams, A., Lowy, P. H., and Borsook, H. Preparation of 1-amino-1-deoxy-2-keto hexoses from aldohexoses and $\alpha$-amino acids. I. J. Amer. chem. Soc. 1955, 77, 4794.

56. Glasstone, S. Textbook of Physical Chemistry, 2nd ed. New York, D. Van Nostrand Co., Inc., 1946.

57. Rapoport, S., and Hofmann, E. C. G. Untersuchungen über den Atmungsstoffwechsel von Reticulocyten. Biochem. Z. 1955, 326, 493.

58. Schweiger, H. G., Rapoport, S., and Schölzel, E. Role of non-protein nitrogen in the synthesis of haemoglobin in the reticulocyte in vitro. Nature 1956, 178, 141.

59. Hofmann, E. C., and Rapoport, S. Der Einfluss der Hämolyse auf die Atmung von Reticulocyten. Biochem. Z. 1955, 326, 499.
60. Saltman, P., Fiskin, R. D., Bellinger, S. B., and Alex, T. The metabolism of iron by rat liver slices. The effect of chemical agents. J. biol. Chem. 1956, 220, 751.

61. Bessis, M., and Breton-Gorius, J. Etude au microscope électronique du sang et des organes hémopoiétiques dans le saturnisme expérimental. Sem. Hôp. Path. et Biol. 1957, No. IV, 411. (Ann. Rech. méd. 1957, No. 2, 151.)

62. Rosin, A., and Rachmilewitz, M. Studies on bone marrow in vitro: III. The effect of anoxia and hyperoxia on explanted bone marrow. Blood 1948, $3,165$.

63. Thomas, E. D. In vitro studies of erythropoiesis. II. The effect of anoxia on heme synthesis. Blood 1955, 10, 612.

64. Erslev, A. J. The effect of anemic anoxia on the cellular development of nucleated red cells. Clin. Res. 1958, 6, 187.

65. Reimann, F. Retikuläre Substanz und Hämoglobinbildung. Schweiz. Z. Path. 1943, 6, 35.

66. Hearon, J. Z. The configuration of cobaltodihistidine and oxy-bis (cobaltodihistidine). J. nat. Cancer Inst. 1948, 9, 1. 